\begin{tabular}{|c|c|c|}
\hline \multirow[b]{3}{*}{ 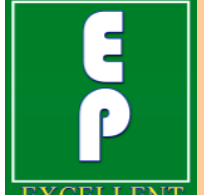 } & International Journal of Current Research in & \\
\hline & Biosciences and Plant Biology & \\
\hline & $\begin{array}{c}\text { ISSN: 2349-8080 (Online) • Volume } 3 \bullet \text { Number } 12 \text { (December-2016) } \\
\text { Journal homepage: www.ijcrbp.com }\end{array}$ & \\
\hline
\end{tabular}

\title{
Further Study on Toxicity of the Permissible (Very Low) Level of Ochratoxin A with and without Essential Oils on Rats
}

\author{
A. M. Abdelhamid1* A. A. M. Abdel Hamid², W. A. Khalilí, A. H. Gomaa ${ }^{3}$ and \\ H. G. M. El-Sayed ${ }^{3}$
}

${ }^{1}$ Department of Animal Production, Faculty of Agriculture, Al-Mansoura University, Egypt

${ }^{2}$ Department of Histology and Cell Biology, Faculty of Medicine, Al-Mansoura University, Egypt

3 Regional Center for Food and Feed, Agricultural Research Center, Cairo, Egypt

*Corresponding author.

\begin{abstract}
A bstract
A feeding experiment was conducted with rats to reevaluate the possible toxic effects of very low level (tolerance limit) of ochratoxin A (OTA) and attempting to overcome this ochratoxicosis A via dietary supplementation of some essential oils. The obtained results revealed that the toxicated as well as garlic-oil groups of rats moisten their mats than the other groups' mats. Garlic-oil group also excreted more wet feces and had the lowest daily bodyweight gain as well as the worst feed conversion ratio comparing with the other groups. Garlic oil containing diets (whether with or without the toxin) reflected very low bone mineral density, whereas all toxic diets (with or without garlic or marjoram oils) and marjoram oil alone reflected high bone mineral concentration but the lowest value was obtained with garlic oil alone. Bone area was increased in all treatments, except garlic oil group. However, the highest area was in marjoram group. Lean mass was the lowest in the toxic diets with or without garlic oil. Fat mass was at lowest value in the toxic diet plus marjoram and the highest in the toxic diet plus garlic oil. OTA and/or the tested essential oils affected also the post-mortem, relative weights (particularly spleen), the blood profile (particularly Glob, Glu, AST, Cre, alkaline phosphatase, LDH, testosterone, lymphocytes, monocytes, and granulocytes), proximate analysis of the biological tissues, and the histological structure of the internal organs. So, even the very low concentration of OTA ( $25 \mathrm{ppb}$, as a dietary tolerance level in some countries) used in this study, it may be harmful and dietary essential oils inclusion could not completely overcome its toxic effects. So, it is still a fact that prevention (of mold growth) is easier, cheaper and more effective and better than curing of mycotoxicosis.
\end{abstract}

\section{Article Info}

Accepted: 28 November 2016

Available Online: 06 December 2016

\section{Ke ywords}

Garlic oil

Marjoram oil

Ochratoxin A

Proximate analysis

\section{Introduction}

The name "ochratoxin" originated from the name of the first fungal species (Aspergillus ochraceus) known to produce this toxin, i.e. the toxin of $A$. ochraceus
(Abdelhamid, 2000). It has biochemical (Zanic-Grubisic et al., 2000), nephrotoxic (Luhe et al., 2003), carcinogenic (Schaaf et al., 2002), immunotoxic (Muller et al., 2003), neurotoxic (Dortant et al., 2001) effects. It affects also fertility (Biro et al., 2003). Ochratoxicoses 
were reported in human (Abdelhamid et al., 1999a) as well in animals (Abdelhamid and Saleh, 1996). The medical plants are not only used in the ancient nations as folkloric drugs but also in the new world as a return to the nature to avoid the negative side effects of the chemical drugs. Many attempts were carried out to utilize from these plants as growth promoters (Abd ElHakim, 2008) or whether to substitute one of the conventional food stuffs in a diet or for their attractive or immunostimulatory effects for their constituents' effects (Tawfik et al., 2005).

Herbs and spices (particularly garlic and marjoram) are one of the most important targets to search for natural antioxidants from the point of view of safety (Yanishlieva et al., 2006). Herbs not only add taste and texture to food, but are also abundant sources of antioxidants, vitamins, minerals, and unique medicinal properties. Herbs have been used since the beginning of human history as a food source and to cure specific aliments, increase strength and endurance and to improve overall health. Ancient people gathered local herbs for food and discovered that each herb also possessed specific healing properties. Herbal oils have their own set of uses and benefits, from food preparation to skin therapy and other practical uses (Mercola, 2016). Therefore, the aim of the present study was to investigate the effects of dietary OTA without or with the dietary addition of essential oils (mainly garlic and marjoram oils) on rats' performance, clinical symptoms, postmortem examination, blood hematology and biochemistry, immunity, muscular biochemistry, and internal organs' histology.

\section{Materials and methods}

The present study aimed to investigate the effects of dietary OTA without or with the dietary addition of essential oils (mainly garlic and marjoram oils) on rats' performance, clinical symptoms, post-mortem examination, blood hematology and biochemistry, immunity, skeletal deformity, muscular biochemistry, and internal organs' histology in a feeding trial lasted for 17 days after 5 days adaptation period.

\section{Experimental animals and housing}

Forty two laboratory white male rats (Wistar) were purchased from the local market weighing in average $89.5 \pm 2.19 \mathrm{~g}$ were divided into six treatments, each in a plastic crate (containing 7 rats) with the dimensions of $37 \times 27 \times 18 \mathrm{~cm}$ (length, width, and height, respectively).
Each crate floor was covered with dry-clean-coarse sawdust which was changed every 4 days. Each crate was provided with feeder and drinking water bottle. All crates were kept under similar environmental conditions in a well aerated room under natural lighting. After the adaptation period, the sawdust was changed with another dry one. Animals of each treatment were individually market at their tails and the experimental crates were numbered too.

\section{Experimental diets}

Commercial pelleted diet (contained $21 \%$ crude protein, $3 \%$ crude fat, less than $5 \%$ crude fiber, and 3190 $\mathrm{kcal} / \mathrm{kg}$ ) was used as a basal (control, $1^{\text {st }}$ treatment, $\mathrm{T}_{1}$, which was used also for feeding all rats foe 5 days as adaptation period) diet (BD). The $2^{\text {nd }} \operatorname{diet}\left(\mathrm{T}_{2}\right)$ was the $\mathrm{T}_{1}+$ OTA at the level of $25 \mathrm{ppb}$ (ng/g diet). The $3^{\text {rd }}$ diet $\left(\mathrm{T}_{3}\right)$ was the $\mathrm{T}_{2}+$ garlic oil $(\mathrm{GO})$ at $1.5 \mathrm{ml} / 100 \mathrm{~g}$ diet. The $4^{\text {th }}\left(\mathrm{T}_{4}\right)$ was the $\mathrm{T}_{2}+$ marjoram oil $(\mathrm{MO})$ at 1.5 $\mathrm{ml} / 100 \mathrm{~g}$ diet. The $5^{\text {th }}$ diet was $\mathrm{T}_{1}+$ garlic oil at 1.5 $\mathrm{ml} / 100 \mathrm{~g}$ diet. Whereas the $6^{\text {th }}$ diet was $\mathrm{T}_{1}+$ marjoram oil at $1.5 \mathrm{ml} / 100 \mathrm{~g}$ diet. The experimental diets were offered once a day at night when rats are active, since most of food intake takes place during the dark period (Koolhaas, 2001) and rats are lazy during day light. Garlic oil and marjoram oil were purchased from the local market. Each essential oil was in a 30-ml brown bottle. The crystalline mycotoxin was dissolved and diluted by chloroform to be sprayed into the toxic diets , T2, T3, and T4 whereas garlic and marjoram oils were diluted too by chloroform and sprayed into diets of T3, T4, T5, and T6, respectively. All diets were air dried to evaporate the solvent for two hours then kept individually in plastic containers in refrigerator till be used for feeding the experimental rat's groups. Eighty three $\mathrm{g}$ of each experimental diet were moisten with little volume of water and hand pressed then offered to the perspective group of animals ( 7 rats/ treatment). Three hundred $\mathrm{ml}$ of tap water were filled into each drinker for each treatment and offered at the same time of offering the diet (at night).

\section{Criteria measured}

Individual rats within each treatment were tail marked to follow up their concerning bodyweights for further statistical analysis of the collected data. Bodyweight changes, feed intake, and water consumption were measured periodically; besides bone image, postmortem, biological tissues analysis and histological examination. 


\section{Blood sampling and analytical methods}

Two blood samples (one for plasma separation for the biochemical determinations while the second for the hematological estimations) had been collected from each of 3 rats / group at the end of the experiment from orpotal venous plexus behind the rat's eye. Adequate amount of whole blood was withdrawn in small plastic vials containing EDTA (ethylene-diamine-tetra-acetic acid) as anticoagulant and used to obtain the blood plasma by centrifuge at $3500 \mathrm{rpm}$ for $15 \mathrm{~min}$. Blood plasma samples were used for biochemical determinations using Jenway 6051 British colorimeter and Human and Spinreact commercial kits for colorimetric determination of the end point.

Tumors' indicators and hormone determination were estimated by German Siemens apparatus and kits. Globulin level was calculated by subtracting albumin from total protein. The other samples of blood were used to determine the complete blood picture using Mindray B-C 3000 plus apparatus and German Mindray commercial kits.

\section{Bone image}

Rats from different experimental groups were subjected to X-ray photograph using the American NORLAND XR-46 to evaluate bone image, bone mineral density (BMD, $\mathrm{g} / \mathrm{cm}^{2}$ ) bone mineral content (BMC, g), area $\left(\mathrm{cm}^{2}\right)$, lean mass $(\mathrm{g})$, and fat mass $(\mathrm{g})$.

\section{Post-mortem examination}

At the end of the feeding period, and after twelve hours fasting period, three animals per treatment were narcotized via chloroform then opened from the abdominal side for gross clinical examine, collecting samples of the internal organs for histopathological examination and chemical analysis, and taking muscles' samples (from back and thigh muscles) for chemical analysis too.

\section{Proximate analysis}

At the end of the experiment, the mats and some internal organs (liver, spleen, and kidney) and flesh (from the back and leg muscles) composite samples from 3-5 rats (randomly) / treatment were assayed to determine the moisture, crude protein, ether extract and ash contents using the official methods of analysis (AOAC, 2000).

\section{Histological examination}

The treated animals and their controls were slaughtered, quickly dissected and their kidney, liver and testis were removed, sliced and fixed in 10\% formalin solution. After $72 \mathrm{hrs}$, tissues were rinsed three times in $70 \%$ ethanol, dehydrated using a graded ethanol series and then embedded in paraffin wax. Paraffin sections were cut into 5-6 micrometers thick slices, stained with haematoxylin and eosin and examined under light microscope.

\section{Statistical analysis}

All obtained data were analyzed using one-way analysis of variance according to statistical analysis system software (SAS, 2006) for windows. One way analysis of variance and (Duncan, 1955) multiple range test were used to compare between the parameters of the different nutritional group. The differences were significant at 0.05 levels.

\section{Results and discussion}

Ochratoxin A (OTA) is found naturally in different environmental conditions, countries, and commodities at different concentrations for the outspreading of its producing fungi (so, it occurs in Egypt). It could negatively affect both animal and human health (Abdelhamid, 2005; Abdelhamid and Saleh, 1996; and Abdelhamid et al., 1996). Ochratoxin A is among mycotoxins that are causative agents for human foodborne poisoning under Egyptian conditions (Abdelhamid et al., 1999a).However, the presence of chamomile, cinnamon or pepper could act as preservers against fungal multiplication or fungicides (Abdelhamid et al., 1985). Moreover, autoclaving may reduce the concentration of OTA by $11-28 \%$ (Abdelhamid et al., 1998).

\section{Feed intake and water consumption}

Although there was no mortality among the experimental animals; yet, the toxicated as well as garlic-oil groups of rats moisten their mats, so appeared collective-dark colored than the other groups' mats. The experimented rats fed daily restricted amount of food, being $83 \mathrm{~g} / 7$ rats, i.e. $11.86 \mathrm{~g} / \mathrm{rat}$, since Koolhass (2001) reported the daily food intake of Wistar rats as $10 \mathrm{~g} / 100 \mathrm{~g}$ bodyweight. However, Abdelhamid et al. (2005) and Abdelhamid and Saleh (2000) mentioned that feeding animals the mycotoxin contaminated foods decreased 
food intake. The daily water consumption increased by age advance as well as during the hot climate days. However, there were no significant $(p \geq 0.05)$ differences among treatments concerning daily drinking water consumption, being 29.0, 27.1, 25.6, 26.2, 27.1, and 27.2 $\mathrm{ml} /$ rat for T1, T2, T3, T4, T5, and T6, respectively. In this respect, Koolhass (2001) reported the daily water intake of Wistar rats as $10-15 \mathrm{ml} / 100 \mathrm{~g}$ bodyweight. However, at the end of the experiment, each crate was provided with $200 \mathrm{~g}$ clean-dry sawdust which was weighed $2^{\text {nd }}$ to represent the excreted urine from each treatment, being $92,78,77,80,120$, and $82 \mathrm{ml} / 7$ rats; i.e. $13.1,11.1,11.0,11.4,17.1$, and $11.7 \mathrm{ml} / \mathrm{rat}$ in $\mathrm{T}_{1}, \mathrm{~T}_{2}, \mathrm{~T}_{3}$, $\mathrm{T}_{4}, \mathrm{~T}_{5}$, and $\mathrm{T}_{6}$, respectively confirming that $\mathrm{T}_{5}$ (fed garlic oil alone) moisten the mattress (Fig. 48). The same group $\left(\mathrm{T}_{5}\right)$ also excreted more wet feces as follow 5.29, 4.57, 4.57, 4.29, 6.71, and $5.00 \mathrm{~g} / \mathrm{rat}$ in $\mathrm{T}_{1}, \mathrm{~T}_{2}, \mathrm{~T}_{3}, \mathrm{~T}_{4}, \mathrm{~T}_{5}$, and $\mathrm{T}_{6}$, respectively. Moreover, the moisture determination of the mats and feces revealed that $\mathrm{T}_{5}$ gave the highest moisture \%, (being 25.5 and 38.6, respectively); since the moisture \% were 17.3, 14.6, 17.8, 16.5, 25.5, and $14.0 \%$ for the mats and $26.3,22.9,17.9,25.7,38.6$, and $17.0 \%$ for the feces of the 6 treatments, respectively. In this concern, Koolhass (2001) reported the daily urine and feces excretion of Wistar rats as $10-15 \mathrm{ml} / 24 \mathrm{~h}$ and 9-13 g/24 h, respectively.

\section{Body weight}

Body weight of the experimented rats did not significantly $(p \geq 0.05)$ differ among the different treatments throughout the three weights (at the start, mid, and at the end of the experiment). The average initial body weight was $89.6 \pm 2.19 \mathrm{~g} / \mathrm{rat}$, whereas the final body weight was $87.0 \pm 13.3,96.3 \pm 9.93,84.4 \pm 3.73,83.4 \pm$ $3.53,93.9 \pm 2.30$, and $92.4 \pm 5.56 \mathrm{~g} /$ rat for $\mathrm{T} 1, \mathrm{~T} 2$, T3, T4, T5, and T6, respectively (Fig. 1). Moreover, the daily body weight gain ranged from 3.66, 3.38, 3.38, 3.49, 3.03 , to $3.32 \mathrm{~g}$ for the same six treatments respectively. Abdelhamid et al. (2005) mentioned that feeding animals the mycotoxin contaminated foods affects food and water intake, as well as body weight. Similar to ochratoxin, another nephritic mycotoxin, i.e. oxalic acid, led to lower body weight gain of rabbits (Abdelhamid and Saleh, 2000). However, OTA is strong carcinogenic, mutagenic and cytotoxic factors are also known to evoke a decrease of food intake and body weight gains (Szkudelska et al., 2005). Yet, Ali et al. (1984) reported a slight increase in body weight of pigeons treated with OTA. However, water thyme extract was better than lemon leaves extract and chamomile flowers' extract in improving daily bodyweight gain, feed conversion, water consumption, nutrients digestibility, and carcass traits of rabbits (Said, 2016). Generally, the differences among studies are due to the experimental animal species as well as dose, rote and duration of the toxin application.

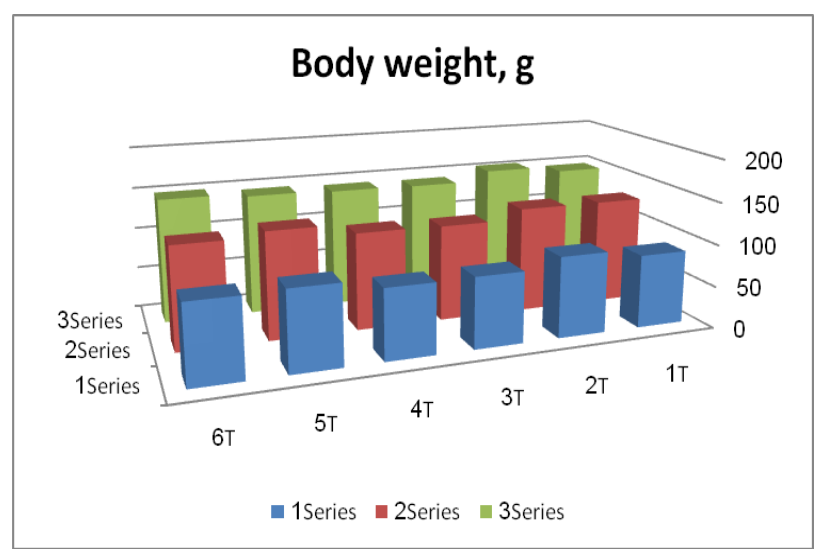

Fig. 1: Body weight changes (throughout three intervals) of the experimented rats fed 6 tested diets.

\section{Food conversion ratio}

Food conversion ratio did not differ among treatments, being $3.24,3.51,3.51,3.40,3.91$, and 3.57 for $\mathrm{T} 1$, T2, T3, T4, T5, and T6, respectively; yet, the best was T1 and the worst was T5. Abdelhamid et al. (1992a) found that mycotoxin contamination, particularly with OTA, negatively affect nutrients digestibility. Moreover, Abdelhamid et al. (2005) reported decreased body weight gain, food intake and conversion, and nutrients digestibility. Similar to ochratoxin, another nephritic mycotoxin; i.e. oxalic acid, led to decrease of food intake and lower food conversion of rabbits (Abdelhamid and Saleh, 2000). From the toxigenic fungi, Aspergillusochraceus producing OTA is widespread in cultivated soils, but has also been documented in uncultivated soils, grains, and food products (Abdelhamid, 2000). Therefore, OTA is frequently occurred in the Egyptian commodities (Abdelhamid, 1983, 1990, 1993, 2004; Abdelhamid and Saleh, 1996 and Abdelhamid et al., 1996 and 1998). So, ochratoxin A is a causative agent in human (Abdelhamid et al., 1999a) and animal (Abdelhamid, 2005 and Abdelhamid et al., 1999b) food poisoning under Egyptian conditions. Yet, OTA in an in vitro (rumen fermentation) study did not alter dry matter and organic matters digestibility, but even the lower concentration slightly improved these digestibilities by Berseem hay and wheat straw (Abdelhamid et al., 1992a). Mycotoxins cause a decrease in consumption or rejection of feed by animals, reducing the absorption of nutrients and impaired metabolism (CAST, 2003). The biological effects of mycotoxins 
depend on the ingested amounts, and time of exposure and animal sensitivity (Yiannikouris and Jouany, 2002; Binder, 2006). Phytogenics are essential oils, plant extracts, botanicals or phytobiotics, i.e. naturally occurring compounds derived from plants that improve gut health and overall digestive health and have proven antioxidant, anti-inflammatory and antimicrobial effects. Oils are probably of great focus (Broom et al., 2016; Syriopoulos et al., 2016; Wijma, 2016).

\section{Bone image}

The following Tables 1-5 illustrate bone mineral density $\left(\mathrm{BMD}, \mathrm{g} / \mathrm{cm}^{2}\right.$ ), bone mineral content (BMC, g), bone area $\left(\mathrm{cm}^{2}\right)$, lean mass $(\mathrm{g})$, and fat mass $(\mathrm{g})$ of the tested rats. It is clear from Table 1 that BMD was very low in the total animal for $\mathrm{T}_{3}$ and $\mathrm{T}_{5}$ and in the leg of $\mathrm{T}_{5}$; yet, the leg of $\mathrm{T}_{4}$ had high BMD.

BMC was high in all parts of animals from $\mathrm{T}_{2}, \mathrm{~T}_{3}$, and $\mathrm{T}_{4}$ as well as in the total body of $\mathrm{T}_{6}$ but the lowest value was obtained from $\mathrm{T}_{5}$ (Table 2 ). Bone area was increased in each part as well as in the total body of all treatments except $\mathrm{T}_{5}$. However, the highest area was in $\mathrm{T}_{6}$ followed by $\mathrm{T}_{3}$ (Table 3 ). Lean mass (Table 4) was the lowest in all parts of $\mathrm{T}_{3}$ and in leg of $\mathrm{T}_{2}$. Fat mass (Table 5) was at lowest value in all parts of $\mathrm{T}_{4}$ and the highest in $\mathrm{T}_{3}$.

Table 1. Bone mineral density (BMD, $\left.\mathrm{g} / \mathrm{cm}^{2}\right)$ of the tested rats at the end of feeding period.

\begin{tabular}{lllllll}
\hline Region & Control & Ochratoxin & $\begin{array}{l}\text { Ochratoxin }+ \\
\text { garlic oil }\end{array}$ & $\begin{array}{l}\text { Ochratoxin+ } \\
\text { marjoram oil }\end{array}$ & Garlic oil & Marjoram oil \\
\hline Leg & 0.1056 & 0.1023 & 0.1003 & 0.1128 & 0.0976 & 0.1047 \\
Spleen & 0.1053 & 0.1066 & 0.1030 & 0.1079 & 0.1015 & 0.1025 \\
Head & 0.1376 & 0.1424 & 0.1289 & 0.1403 & 0.1314 & 0.1285 \\
Total & 0.1191 & 0.1199 & 0.1130 & 0.1223 & 0.1128 & 0.1138 \\
\hline
\end{tabular}

Table 2. Bone mineral content (BMC, g) of the tested rats at the end of feeding period.

\begin{tabular}{lllllll}
\hline Region & Control & Ochratoxin & $\begin{array}{l}\text { Ochratoxin }+ \\
\text { garlic oil }\end{array}$ & $\begin{array}{l}\text { Ochratoxin+ } \\
\text { marjoram oil }\end{array}$ & Garlic oil & Marjoram oil \\
\hline Leg & 0.9511 & 1.028 & 1.252 & 1.188 & 0.7443 & 1.471 \\
Spleen & 0.5955 & 0.8229 & 0.8293 & 0.9125 & 0.5491 & 0.9056 \\
Head & 1.514 & 1.710 & 1.710 & 1.622 & 1.189 & 1.898 \\
Total & 3.090 & 3.543 & 3.664 & 3.541 & 2.448 & 4.209 \\
\hline
\end{tabular}

Table 3. Bone area $\left(\mathrm{cm}^{2}\right)$ of the tested rats at the end of feeding period.

\begin{tabular}{lllllll}
\hline Region & Control & Ochratoxin & $\begin{array}{l}\text { Ochratoxin }+ \\
\text { garlic oil }\end{array}$ & $\begin{array}{l}\text { Ochratoxin+ } \\
\text { marjoram oil }\end{array}$ & Garlic oil & Marjoram oil \\
\hline Leg & 9.006 & 10.04 & 12.49 & 10.53 & 7.624 & 14.04 \\
Spleen & 5.656 & 7.719 & 8.049 & 8.460 & 5.410 & 8.837 \\
Head & 11.00 & 12.01 & 13.27 & 11.56 & 9.049 & 14.77 \\
Total & 25.95 & 29.54 & 32.43 & 28.97 & 21.70 & 36.98 \\
\hline
\end{tabular}

Table 4. Lean mass $(\mathrm{g})$ of the tested rats at the end of feeding period.

\begin{tabular}{lllllll}
\hline Region & Control & Ochratoxin & $\begin{array}{l}\text { Ochratoxin }+ \\
\text { garlic oil }\end{array}$ & $\begin{array}{l}\text { Ochratoxin+ } \\
\text { marjoram oil }\end{array}$ & Garlic oil & Marjoram oil \\
\hline Leg & 45.77 & 38.93 & 44.15 & 49.51 & 47.95 & 52.16 \\
Spleen & 75.80 & 79.13 & 53.41 & 81.97 & 64.05 & 72.86 \\
Head & 38.13 & 47.32 & 40.63 & 36.60 & 36.13 & 41.39 \\
Total & 160.7 & 156.0 & 131.1 & 155.1 & 145.6 & 159.1 \\
\hline
\end{tabular}

Table 5. Fat mass $(\mathrm{g})$ of the tested rats at the end of feeding period.

\begin{tabular}{lllllll}
\hline Region & Control & Ochratoxin & $\begin{array}{l}\text { Ochratoxin }+ \\
\text { garlic oil }\end{array}$ & $\begin{array}{l}\text { Ochratoxin+ } \\
\text { marjoram oil }\end{array}$ & Garlic oil & Marjoram oil \\
\hline Leg & 1.546 & 1.315 & 4.031 & 0.6517 & 2.864 & 3.115 \\
Spleen & 2.561 & 2.673 & 4.876 & 1.079 & 3.825 & 4.352 \\
Head & 1.288 & 1.599 & 3.709 & 0.5082 & 2.158 & 2.472 \\
Total & 5.430 & 5.269 & 11.97 & 2.041 & 8.696 & 9.499 \\
\hline
\end{tabular}


Abdelhamid et al. (1990 and 1995a) found that feeding animals the mycotoxin contaminated foods affects their bone structure and analysis. Moreover, Abdelhamid et al. (2002b) noticed that feeding mycotoxin-contaminated diets reduced the muscles' area in the experimental animals. Since OTA-induced immunosupression in animals suggests that it may be related to the inhibitory effect of OTA on DNA and protein synthesis (Donmez-Altuntas et al., 2003; Muller et al., 2003). Medical plants (Abd El-Hakim, 2008) are used whether to substitute one of the conventional food stuffs in a diet or for their attractive or immunostimulatory effects on animals. Garlen Allicin was responsible for the highest $\mathrm{CP}$ percentage and the lowest $\mathrm{EE}$ and energy contents in the whole fish body (Abdelhamid et al., 2014). Recently, Magouz et al. (2016) found that aflatoxin negatively affected fish chemical composition and muscular and abdominal areas. Yet, detoxification via chemical (Filofeed Plus), biological (Cap T2), and spices (black pepper) means was beneficial in reducing the mycotoxicosis symptoms.

\section{Postmortem examination}

The post-mortem examination revealed that the internal organs of the control group's rats appeared shining normal and the blood was normal red reflected strong toxicity symptoms, i.e. small volume of viscose-dark colored blood compared with enlarged-dark colored spleen. All the internal organs reflecting viability of the control rats were taken in to account. The second group fed the ochratoxic diet was responsible for pale flesh, not shining, and friable. That means that the ochratoxic rats were less viable. The third group (ochratoxic diet plus garlic oil) showed better PM than the second group (ochratoxic) concerning the blood velocity, color and volume as well as the size of each internal organ. The forth group (ochratoxic diet plus marjoram oil) showed better PM than the second group (ochratoxic) concerning the blood velocity, color and volume as well as the size of each internal organ, except spleen which was slightly enlarged besides the presence of abdominal fat deposition. The fifth group's animals (fed the control diet plus garlic oil) were viable, since the blood volume was large, bright red colored, and flood. The fat deposition in the abdominal cavity was absent all internal organs and flesh was bright and contacted with normal sizes. The sixth group of the experimental rats fed the control diet plus marjoram oil showed also normal blood volume, flood and color and little fat deposition in the abdominal cavity. All internal organs and flesh were bright and contacted with normal sizes. Abdelhamid et al. (1990) found that feeding animals the mycotoxin contaminated foods led to fat deposition and discoloration in the internal organs. Moreover, Abdelhamid et al. (1995a) reported some post-mortem findings by animal mycotoxicosis, including discoloration, congestion, and friable muscles and organs. Additionally, Abdelhamid et al. (1999b) reported post-mortem examination of acute-ochratoxic-rabbits included haemorragic patches on the internal organs and dilated kidneys. Concerning the use of natural medicinal plants, garlic (Biogen $\left.{ }^{\circledR}\right)$ is used to detoxify aflatoxic diets of fish (Abdelhamid et al., 2002a). Moreover, medicinal herbs (thyme, safflower, ginger, black cumin and/or garlic) were used also attempting to reduce or treat the aflatoxicosis symptoms by rats (Abdelhamid et al., 2002b).

\section{Internal organs relative weight}

There were no significant ( $p \geq 0.05)$ differences among the experimental treatments in liver and kidneys' relative weights; yet, spleen relative weight was significantly $(p \leq 0.05)$ higher in $T_{3}$ reflecting the interaction between OTA and garlic oil (Table 6).

Table 6. Relative weight (\% of live body weight) of some internal organs of the experimental rats as means of five observations \pm standard errors.

\begin{tabular}{lllc}
\hline Treatments No. & Liver & Spleen & Kidneys \\
\hline 1 & $3.76 \pm 0.26$ & $0.60^{\mathrm{b}} \pm 0.06$ & $0.86 \pm 0.15$ \\
2 & $4.38 \pm 0.30$ & $0.64^{\mathrm{b}} \pm 0.07$ & $1.04 \pm 0.17$ \\
3 & $4.66 \pm 0.34$ & $1.16^{\mathrm{a}} \pm 0.15$ & 1.16 \\
4 & $4.91 \pm 0.54$ & $0.88^{\mathrm{ab}} \pm 0.16$ & 0.15 \\
5 & $4.88 \pm 0.54$ & $0.51^{\mathrm{b}} \pm 0.12$ & $1.09 \pm 0.23$ \\
6 & $4.83 \pm 0.23$ & $0.70^{\mathrm{ab}} \pm 0.16$ & $1.13 \pm 0.17$ \\
\hline
\end{tabular}

a-b: Means in the same column superscripted with different letters differ significantly $(p \leq 0.05)$.

In this concern, Koolhass (2001) reported the relative weights of liver, spleen and kidneys of Wistar rats as 3.0, 0.2 , and $1.0 \%$, respectively. Ali et al. (1984) reported a slight increase in the weight of pigeons' kidney, liver, heart and spleen when treated with OTA. Abdelhamid et al. (1990 and 2005) mentioned that feeding animals 
the mycotoxin contaminated foods increased their relative weights of liver, kidney, heart, spleen, testes, and adrenal glands. Similar to ochratoxin, another nephritic mycotoxin; i.e. oxalic acid, led to increase of relative weight of either liver and kidneys of rabbits (Abdelhamid and Saleh, 2000). Moreover, Abdelhamid et al. (2002c) noticed that feeding mycotoincontaminated diets increased relative weight of spleen in the experimental animals. Magouz et al. (2016) found that aflatoxin negatively affected fish performance, food utilization, and organs indices. Yet, detoxification via chemical (Filofeed Plus), biological (Cap T2), and spices (black pepper) means was beneficial in reducing the mycotoxicosis symptoms.

\section{Blood picture}

Means \pm standard errors of different biochemical and hematological parameters measured in the experimental rats' blood at the end of the feeding period are presented in Tables 7 and 8 . There were no significant $(p \geq 0.05)$ differences among different experimental treatments in either of TP, Alb, ALT, UA, CEA, AP, T.PSA, amylase, WBC, Hg, RBC, Hct, MCV, MCH, MCHC, RDW-CV,
RDW-SD, Plt., MPV, PDW or Pct. Yet, OTA contaminated diet No. 2 lowered Glob and raised Glu levels, but not significantly ( $p \geq 0.05)$. The OTA alone or the marjoram-oil diets decreased significantly $(p \leq 0.05)$ the activity of alkaline phosphatase whereas diet 3 (OTA+garlic oil) significantly $(p \leq 0.05)$ increased its activity; its lowest activity was given by rat group No. 1 (control). Diet No. 3 (OTA+garlic oil) reflected significantly $(p \leq 0.05)$ the lowest Gran. \% whereas its highest percentage was obtained with rats fed the toxic diet+marjoram oil followed by the toxic diet. Garlic oil raised the globulin concentration significantly $(p \leq 0.05)$ than on the toxigenic diets. Diet 3 (OTA+garlic oil) elevated the activity of AST than on all other diets. Garlic oil alone (diet 5) raised significantly $(p \leq 0.05)$ the creatinine concentration than of control, toxic diet, and marjoram oil, the lowest value was obtained by the control rats. Diet 3 gave the highest Lymph. \%, even than the control, whereas the lowest \% was obtained with diet 4 (toxin+marjoram oil) which was near the other diets except No. 3. Garlic oil (diet 5) reflected the highest Mid. \%, whereas the other diets did not significantly $(p \geq 0.05)$ differ between each other.

Table 7. Mean values* of the biochemical parameters (means \pm standard errors) determined in rats fed the experimental diets for 17 days.

\begin{tabular}{|c|c|c|c|c|c|c|}
\hline \multirow{2}{*}{ Criteria } & \multicolumn{6}{|c|}{ Experimental groups No. } \\
\hline & 1 & 2 & 3 & 4 & 5 & 6 \\
\hline Total protein, $\mathrm{TP}, \mathrm{g} / \mathrm{dl}$ & $8.23 \pm 0.15$ & $7.53 \pm 0.55$ & $7.93 \pm 0.44$ & $7.70 \pm 0.35$ & $8.83 \pm 0.29$ & $8.37 \pm 0.41$ \\
\hline Albumin, Alb. g/dl & $4.17 \pm 0.72$ & $4.07 \pm 0.43$ & $4.23 \pm 0.55$ & $4.43 \pm 0.62$ & $3.67 \pm 0.09$ & $3.57 \pm 0.12$ \\
\hline Globulin, Glob, g/dl & $4.07 \mathrm{abc} \pm 0.83$ & $3.47 b \pm 0.23$ & $3.70 b \pm 0.27$ & $3.27 b \pm 0.58$ & $5.17 a \pm 0.22$ & $4.80 \mathrm{ac} \pm 0.30$ \\
\hline Glucose, Glu, mg/dl & $62.0 b \pm 6.35$ & $78.0 \mathrm{ab} \pm 6.24$ & $70.7 b \pm 0.88$ & $83.3 \mathrm{ab} \pm 5.61$ & $72.3 b \pm 4.70$ & $89.7 \mathrm{a} \pm 0.88$ \\
\hline AST, U/l & $167 \mathrm{ab} \pm 7.86$ & $136 \mathrm{ab} \pm 18.3$ & $192 \mathrm{a} \pm 20.0$ & $119 b \pm 10.7$ & $170 \mathrm{ab} \pm 18.5$ & $117 \mathrm{~b} \pm 11.2$ \\
\hline Creatinine, Cre, mg/dl & $0.49 b \pm 0.06$ & $0.57 b \pm 0.03$ & $0.64 a b c \pm 0.11$ & $0.73 \mathrm{ac} \pm 0.09$ & $0.77 \mathrm{a} \pm 0.02$ & $0.56 b \pm 0.08$ \\
\hline Uric Acid, UA., mg/dl & $2.07 \pm 0.27$ & $1.83 \pm 0.20$ & $2.40 \pm 0.23$ & $1.63 \pm 0.34$ & $2.07 \pm 0.09$ & $1.80 \pm 0.12$ \\
\hline Cholesterol, mg/dl & $78.9 \pm 21.7$ & $97.0 \pm 13.8$ & $86.3 \pm 28.0$ & $66.8 \pm 12.0$ & $74.6 \pm 5.01$ & $79.3 \pm 6.70$ \\
\hline Triglycerides, mg/dl & $75.2 \pm 36.1$ & $67.5 \pm 18.5$ & $63.8 \pm 7.67$ & $75.3 \pm 28.6$ & $87.9 \pm 17.4$ & $66.9 \pm 2.88$ \\
\hline HDL, mg/dl & $24.3 \pm 5.66$ & $31.3 \pm 1.35$ & $38.2 \pm 16.0$ & $27.4 \pm 3.01$ & $25.7 \pm 5.39$ & $30.2 \pm 0.99$ \\
\hline Amylase, U/1 & $544 \pm 30.4$ & $581 \pm 19.9$ & $503 \pm 16.6$ & $582 \pm 29.9$ & $644 \pm 34.8$ & $660 \pm 82.8$ \\
\hline Testosterone, $\mathrm{ng} / \mathrm{ml}$ & $9.80 \mathrm{a} \pm 1.91$ & $5.57 \mathrm{abc} \pm 3.11$ & $1.87 \mathrm{~b} \pm 0.07$ & $1.43 b c \pm 0.45$ & $0.47 c \pm 0.17$ & $1.40 b c \pm 0.36$ \\
\hline AFP, ng/ml & $0.30 \pm 0.00$ & $0.25 \pm 0.05$ & $0.25 \pm 0.05$ & $0.35 \pm 0.05$ & $0.20 \pm 0.00$ & $0.25 \pm 0.05$ \\
\hline $\mathrm{CEA}, \mathrm{ng} / \mathrm{ml}$ & $5.80 \pm 0.00$ & $5.80 \pm 0.00$ & $5.80 \pm 0.00$ & $5.80 \pm 0.00$ & $5.80 \pm 0.00$ & $5.80 \pm 0.00$ \\
\hline T. PSA, ng/ml & $0.04 \pm 0.00$ & $0.04 \pm 0.00$ & $0.04 \pm 0.00$ & $0.06 \pm 0.02$ & $0.04 \pm 0.00$ & $0.04 \pm 0.00$ \\
\hline
\end{tabular}


Marjoram oil (diet 6) increased the globulin concentration significantly $(p \leq 0.05)$ than in the toxic diets. Diet 6 also increased significantly $(p \leq 0.05)$ the glucose level than all other diets. Diets 4 and 6 lowered the activity of AST comparing with diet 3. Diets 3, 4, and 5 gave the highest activity of alkaline phosphatase (diet $3>4>5$ ). All tested treatments decreased the testosterone, particularly garlic oil (the worst level), marjoram oil, toxin+marjoram, then the toxin+garlic. Diet 4 followed by diet 6 reflected the significantly $(p \leq 0.05)$ lowest activity of LDH, whereas diet 3 gave insignificantly $(p \geq 0.05)$ higher activity than diets 1 and 2 . It was clear that $\mathrm{ON}$ reduced blood proteins and lymphocytes count, i.e. reduced the immunity of the experimented rats. Yet, garlic oil improved the blood proteins level, particularly in diet 5, i.e. raised the immunity (globulin and lymphocytes) of the rats. Herbs' oils, particularly marjoram alone, increased blood sugar level but reduced AST-activity and $\mathrm{WBC}_{\mathrm{s}}$ count. All diets reduced the blood testosterone concentration comparing with the control, particularly $(p \leq 0.05)$ in the presence of either oil. Ali et al. (1984) reported a decrease in the intestinal glucose absorption rate, blood concentration of glucose and cholesterol, as well as the amylase activity, but total nitrogen was increased in pigeons treated with OTA. Uncontrolled storage of foods damages these foods physically. Moreover, feeding the animals these spoiled foods led to unappetite, changes in the blood profile, and suspect of hepatitis and nephritis, so Abdelhamid et al. (1990, 1992b, 1994 and 1995b and Mahmoud et al., 1994) found that feeding animals the mycotoxin contaminated foods affects their blood picture. In addition, Abdelhamid et al. (1999b) reported increases in blood concentrations of creatinine, urea, uric acid, and cholesterol and transaminases activity; whereas, decrease of blood total protein concentration was recorded in acute-ochratoxic-rabbits. Similar to OTA, another nephritic mycotoxin; i.e. oxalic acid, led to significant increase of blood transaminases activity and cholesterol creatinine, and uric acid, and decrease in blood total protein level of rabbits (Abdelhamid and Saleh, 2000). Moreover, Abdelhamid et al. (2002c) noticed that feeding mycotoin-contaminated diets increased the albumin/globulin ratio, transaminases activity, but reduced blood acid phosphatase activity in the experimental animals.

Table 8. Mean values* of the hematological parameters (means \pm standard errors) determined in rats fed the experimental diets for 17 days.

\begin{tabular}{|c|c|c|c|c|c|c|}
\hline \multirow[b]{2}{*}{ Criteria } & \multicolumn{6}{|c|}{ Experimental groups No. } \\
\hline & 1 & 2 & 3 & 4 & 5 & 6 \\
\hline WBCs, $\times 10^{3} / \mu 1$ & $6.47 \pm 0.78$ & $7.03 \pm 2.28$ & $5.90 \pm 0.35$ & $6.30 \pm 0.92$ & $7.40 \pm 1.61$ & $4.37 \pm 0.09$ \\
\hline Lymph., $\times 10^{3} / \mu 1$ & $47.7 \mathrm{ab} \pm 4.80$ & $31.7 b \pm 5.16$ & $51.0 \mathrm{a} \pm 4.02$ & $30.2 b \pm 4.09$ & $31.6 b \pm 0.80$ & $36.0 \mathrm{ab} \pm 4.78$ \\
\hline Mid., $\times 10^{3} / \mu \mathrm{l}$ & $14.0 \mathrm{ab} \pm 2.25$ & $14.7 \mathrm{ab} \pm 1.29$ & $11.5 b \pm 1.06$ & $15.0 \mathrm{ab} \pm 2.85$ & $16.6 \mathrm{a} \pm 0.50$ & $14.2 \mathrm{ab} \pm 0.38$ \\
\hline Gran., $\times 10^{3} / \mu 1$ & $38.3 \mathrm{ab} \pm 5.15$ & $53.6 \mathrm{a} \pm 4.22$ & $37.6 b \pm 2.99$ & $56.2 \mathrm{ab} \pm 6.98$ & $51.8 \mathrm{a} \pm 1.27$ & $49.8 \mathrm{ab} \pm 4.43$ \\
\hline $\mathrm{Hb}, \mathrm{g} / \mathrm{dl}$ & $12.4 \pm 0.77$ & $11.6 \pm 0.33$ & $12.6 \pm 0.31$ & $10.6 \pm 1.11$ & $12.8 \pm 0.50$ & $12.2 \pm 0.27$ \\
\hline $\mathrm{RBCs}, \times 10^{6} / \mu \mathrm{l}$ & $6.65 \pm 0.48$ & $6.38 \pm 0.33$ & $6.63 \pm 0.37$ & $5.92 \pm 0.71$ & $7.02 \pm 0.12$ & $6.69 \pm 0.35$ \\
\hline Hct, \% & $37.9 \pm 2.91$ & $36.4 \pm 0.40$ & $38.8 \pm 1.42$ & $36.8 \pm 2.15$ & $38.2 \pm 1.16$ & $37.9 \pm 0.75$ \\
\hline $\mathrm{MCV}, \mathrm{fl}$ & $57.0 \pm 0.26$ & $59.7 \pm 2.30$ & $58.8 \pm 1.77$ & $63.5 \pm 5.51$ & $54.8 \pm 1.17$ & $56.8 \pm 2.07$ \\
\hline $\mathrm{MCH}, \mathrm{pg}$ & $18.6 \pm 0.19$ & $19.0 \pm 0.32$ & $19.0 \pm 0.86$ & $17.9 \pm 0.34$ & $18.1 \pm 0.59$ & $18.2 \pm 0.63$ \\
\hline $\mathrm{MCHC}, \%$ & $32.7 \pm 0.43$ & $32.0 \pm 0.81$ & $32.5 \pm 0.52$ & $28.6 \pm 2.07$ & $33.2 \pm 0.38$ & $32.2 \pm 0.06$ \\
\hline RDW-CV, \% & $15.2 \pm 0.66$ & $16.3 \pm 1.77$ & $15.3 \pm 0.64$ & $21.9 \pm 3.98$ & $14.3 \pm 0.75$ & $14.4 \pm 0.23$ \\
\hline RDW-SD, fl & $30.9 \pm 0.90$ & $33.9 \pm 4.74$ & $30.9 \pm 1.77$ & $48.1 \pm 10.8$ & $27.3 \pm 0.55$ & $27.9 \pm 1.08$ \\
\hline Plt., $\times 10^{3} / \mu 1$ & $610 \pm 20.6$ & $641 \pm 48.9$ & $580 \pm 46.0$ & $472 \pm 66.2$ & $635 \pm 45.3$ & $623 \pm 55.0$ \\
\hline MPV, fl & $6.60 \pm 0.21$ & $6.60 \pm 0.40$ & $6.23 \pm 0.18$ & $6.23 \pm 0.33$ & $6.03 \pm 0.20$ & $5.97 \pm 0.12$ \\
\hline PDW & $16.7 \pm 0.12$ & $16.1 \pm 0.15$ & $15.8 \pm 0.13$ & $16.2 \pm 0.68$ & $16.0 \pm 0.18$ & $16.0 \pm 0.18$ \\
\hline PCT, \% & $0.40 \pm 0.02$ & $0.42 \pm 0.04$ & $0.36 \pm 0.02$ & $0.30 \pm 0.06$ & $0.39 \pm 0.04$ & $0.37 \pm 0.04$ \\
\hline
\end{tabular}

*: Each value is the mean of 3 rats. a-b:Means in the same row superscripted with different letters differed significantly $(p \leq 0.01)$.WBC: White blood cells. RBC: Red blood cells. Lymph: Lymphocytes. Mid: Monocytes. Gran: Granulocytes. Hb: Hemoglobin. Hct: Hematovrite. MCV: Mean corbuscular volume. MCH: Mean corbuscular hemoglobin. MCHC: Mean corbuscular hemoglobin concentration. RDW-CV: Red cells distribution width-standard deviation. RDW-SD: Red cells distribution width-standard deviation. Plt: Platelets. MPV: Mean platelet volume. PDW: Platelet distribution width. PCT: Platelet crit.

OTA exposure can lead to increased urine volume (so, increased the moisture content of the mats, Fig. 47), blood urea nitrogen (Hatey and Galtier, 1977), urinary glucose, and proteinuria (Berndt and Hayes, 1979) as well as to reductions in the activity of enzymes in the kidney, such as alkaline phosphatase, leucine 
aminopeptidase, and glutamyl transferase (Kane et al., 1986). Although there was no indicator for carcinogenicity due to using the very low level of OTA in the present study, the carcinogenicity of OTA has been established in rodents, with the kidney being the principal site and the liver the major secondary site of tumor formation. Mice fed OTA reflected mortality; surviving mice had hepatic and renal tumors (Kanisawa and Suzuki, 1978). Similar findings were reported in mice by Kanisawa (1984), who found renal cystic adenomas and hepatic tumors, in mice treated with OTA. In mice fed OTA, benign and malignant renal tumors were seen (Bendele et al., 1985). Similar findings have been reported in rats. The frequency of renal adenomas increased in a dose-dependent manner in all groups of male rats treated with OTA (National Toxicology Program, 1989).

The biochemistry of OTA results from its structural similarity to the essential amino acid, phenylalanine (Phe). The effect appears to be inhibition of protein synthesis (Creppy et al., 1984), although effects such as inhibition of RNA and DNA synthesis have also been implicated in its mechanism of action. Applications of specific feed additives which are able to help negate the negative effects of different mycotoxins in animals are highly recommended (Borutova, 2015). On the other hand, OTA is strong carcinogenic, mutagenic and cytotoxic factors. OTA decreased insulin-stimulated lipogenesis. The adipocytes are susceptible to the direct action of OTA. This susceptibility is, however, rather weak and is exhibited by a slight restriction of the lipogenesis (Szkudelska et al., 2005). Most of the obtained blood values are around the normal values given by many authors, e.g. Merck (1976), Abdelhamid (1989 and 1990), Abdelhamid and Saleh (2000), Abdelhamid et al. (1999b), Sadek (2011), Abdel-Khalek et al. (2012), Abu El-Hamd et al. (2013) and El-Medany et al. (2013). Since Merck (1976) gave the normal values for Wistar rats as ca. $14 \mathrm{~g} / \mathrm{dl} \mathrm{Hg}, 8.73 \pm 1.6 \mathrm{x}$ $10^{6} / \mu$ lerythrocytes, $15.56 \pm 2.6 \times 10^{3} / \mu$ lleucocytes, and $77 \pm 13 \mathrm{mg} /$ dlglucose. He added that increased leucocytes count may be due to acidosis and leucosis, whereas its rise (leukopenia) may be attributed to toxic process. Yet, strong effect of OTA on testis (testosterone deficiency because of hypogonadism) resulted in severe decrease in testosterone hormone level in all treatments comparing with control (Kutsky, 1973).

Soliman and Abd El Moty (1974) mentioned that leucopenia (reduced total WBCs) is responsible for weakness of the defensive mechanism of the body and indicates an unfavorable prognosis. It may occur in anemia, starvation, malnutrition and chemical toxicities. In addition, most of plasma lipids are associated with globulin and to some extend with albumin. Albumin and globulins are synthesized in the liver. However, LDH is rather non-specific. Latner (1975) cited that lower transaminases activity may occur in hepatic (portal) cirrhosis, biliary cirrhosis, toxic hepatitis and/or hepatic malignancy. The enzyme LDH is included in carbohydrate metabolism (catalyzes the interconversion of lactate and pyruvate), it is particularly abundant in kidney, skeletal muscle, liver, and myocardium. The activity of LDH is smaller to that of AST in case of myocardial infarction. However, cortisol is a potent inhibitor of the inflammatory reaction induced by physical, chemical and/or bacterial agents. In addition, Varley (1978) mentioned that AST is not specific for myocardial infarction. Whereas, LDH is especially plentiful in cardiac and skeletal muscle, liver, kidney and RBCs. He added that hyperglycemia could be found in cases of hyperactivity of the thyroid, pituitary, and adrenal glands as well as in pancreatitis. Moreover, creatinine is the internal anhydride of creatine, being formed when water is removed. So, plasma creatinine increases in renal disease. He added that increase in globulin occurs in adverse liver disease. Increase of blood protein is mostly compound by globulin increase. Moreover, the increase in LDH activity may relate to kidney disease, tumors of the central nervous system, and increased AST-activity. However, AST figure is often lower than that of ALT. Increase of AST is found in jaundice. In addition, increase in alkaline phosphatase activity is occurring in certain bone disease (osteomalacia, osteitisdeformans "Paget's disease", and bone tumors) and steatorrheas.

At lower levels, OTA has been shown to affect a number of parameters of immune function. Thuvander et al. (1995) reported a reduction in the number of spleenocytes in mice orally administered $2.6 \mathrm{mg} / \mathrm{kg}$ feed, equivalent to $400 \mu \mathrm{g} / \mathrm{kg}$ body weight per day, for 90 days. Prenatal OTA exposure $(200 \mu \mathrm{g} / \mathrm{kg}$ feed, equivalent to $30 \mu \mathrm{g} / \mathrm{kg}$ body weight per day) altered the absolute and relative numbers of lymphocyte subpopulations in lymphoid organs of BALB/C mice, although immune function was not suppressed (Thuvander et al., 1996a). In contrast, exposure of suckling pups to OTA via the milk stimulated the immune response in rats, as shown by the proliferation of lymphocytes in response to an antigen (Thuvander et al., 1996b). In chickens, OTA reduced the lymphoid cell population of immune organs (Dwivedi and Burns, 
1984b), the plasma levels of $\alpha 1-, \alpha 2-, \beta$ - and $\gamma$-globulins (Rupic et al., 1978), and the levels of IgG, IgA and IgM in lymphoid tissues and serum (Dwivedi and Burns, 1984a). Donmez-Altuntas et al. (2003) and Muller et al. (2003) mentioned that the mechanism of OTA-induced immunosupression in animals may be related to the inhibitory effect of OTA on DNA and protein synthesis in lymphocytes, macrophages and other immune system cell types. Some animal studies have indicated that OTA may adversely affect the male reproductive system. Administration of OTA to male rats caused a two-fold increase in the testicular testosterone levels (Gharbi et al., 1993).

Biro et al. (2003) investigated the effects of OTA on spermatogenesis in breeding boars fed OTA. Semen analysis showed that sperm motility and viability were significantly reduced, suggesting that OTA may reduce semen quality. Abdel-Galil (2005) concluded that ochratoxicosis by rats is associated by increased serum transaminases (ALT, AST) and alkaline phosphatase and decreased serum total protein. However, the acute toxicity $\left(\mathrm{LD}_{50}\right)$ of OTA is $20 \mathrm{mg} / \mathrm{kg}$ by rats (Kellerman et al., 1990). However, half-lives for OTA after oral administration have been reported to range 55-230 hours in rats (Zepnik et al., 2003). The probiotic GarlenAllicin reflected the best survival rate, haematological and immunological parameters' values (Abdelhamid et al., 2013). Also, Algedawy et al. (2011) concluded that the probiotic Biogen ${ }^{\circledR}$ is superior to the multienzyme mixture Natuzyme ${ }^{\circledR}$ for improving the cellular and humoral immune responses. The inhibitory effect of the methanol extract of Origanummajorana (marjoram) was used as blood anti-coagulator in Iranian folk medicine. The methanol extract of $O$. majorana inhibited platelet adhesion. These observations provide the basis for the traditional use of this herb in treatments of cardiovascular diseases and thrombosis (Yazdanparast and Shahriyary, 2008).

\section{Chemical analysis}

The following Tables present data of the proximate chemical analysis of some internal organs (liver, spleen, and kidney) and flesh in pooled samples (because of the very low weight of the fresh internal organs), each from 3-5 rats/treatment/tissue at the end of the experimental feeding period. The moisture content (Table 9) was slightly high in liver of $\mathrm{T}_{6}$, spleen of $\mathrm{T}_{5}$ and very high in flesh of $\mathrm{T}_{2}$; but the lowest percentage in liver and spleen was in $T_{2}$, and kidney of $T_{5}$. That means that ochratoxin A was responsible for the exsiccation of liver, spleen, and kidneys but increased water content of the flesh on the account of the dry matter.

Table 9. Moisture content $(\%)$ of some internal organs and flesh of the tested rats at the end of the feeding period.

\begin{tabular}{lllllll}
\hline \multirow{2}{*}{ Tissues } & \multicolumn{7}{l}{ Treatments No. } & $\mathbf{3}$ & $\mathbf{3}$ & $\mathbf{4}$ & $\mathbf{5}$ & \\
\cline { 2 - 7 } & $\mathbf{1}$ & 69.9 & 70.2 & 70.7 & 70.6 & $\mathbf{6}$ \\
\hline Liver & 70.2 & 63.0 & 65.7 & 72.5 & 74.0 & 73.3 \\
Spleen & 72.4 & 71.3 & 66.3 & 69.3 & 64.9 & 69.0 \\
Kidney & 74.4 & 32.1 & 28.3 & 28.0 & 28.4 & 29.3 \\
Flesh & 28.4 & &
\end{tabular}

The crude protein content (\% DM basis) of the tested rats' muscles at the end of the feeding period were lower in all treatments, except in $\mathrm{T}_{3}$, comparing with the control, being 64.9, 63.9, 65.7, 90.9, 63.6, and 60.9, in the six treatments, respectively. The lowest percentage was in $\mathrm{T}_{4}$ (60.9) but the highest was in $\mathrm{T}_{3}(65.7)$. Table 10 shows that all treatments, except $\mathrm{T}_{5}$, reflected higher ether extract (EE) contents in the liver than the control, particularly in $\mathrm{T}_{3}, \mathrm{~T}_{2}$ and $\mathrm{T}_{6}$. On the other hand, spleen of all treatments, except $T_{2}$, contained lower EE than the control. Moreover, kidney of all treatments, without exceptions, had higher EE than the control, particularly in $\mathrm{T}_{5}, \mathrm{~T}_{6}$ and $\mathrm{T}_{2}$. The rats' flesh of $\mathrm{T}_{6}, \mathrm{~T}_{4}$ and $\mathrm{T}_{2}$ reflected higher EE than the control. However, Table 11 proved that all treatments raised the ash percentage of the liver but reduced it in the flesh

Table 10. Ether extract content (\% DM basis) of some internal organs and flesh of the tested rats at the end of the feeding period.

\begin{tabular}{lllllll}
\hline \multirow{2}{*}{ Tissues } & \multicolumn{2}{l}{ Treatments No. } & \multicolumn{3}{l}{} \\
\cline { 2 - 8 } & $\mathbf{1}$ & $\mathbf{2}$ & $\mathbf{3}$ & $\mathbf{4}$ & $\mathbf{5}$ & \\
\hline Liver & 4.25 & 5.82 & 6.34 & 4.70 & 2.86 & $\mathbf{6}$ \\
Spleen & 12.5 & 15.0 & 2.86 & 7.58 & 1.96 & 11.9 \\
Kidney & 20.4 & 28.3 & 25.9 & 26.2 & 36.3 & 28.6 \\
Flesh & 24.9 & 26.4 & 23.5 & 27.8 & 23.9 & 28.3 \\
\hline
\end{tabular}


Table 11. Ash content (\% DM basis) of some internal organs and flesh of the tested rats at the end of the feeding period.

\begin{tabular}{lllllll}
\hline \multirow{2}{*}{ Tissues } & \multicolumn{7}{l}{ Treatments No. } & $\mathbf{2}$ & $\mathbf{3}$ & $\mathbf{4}$ & $\mathbf{5}$ & \\
\cline { 2 - 7 } & $\mathbf{1}$ & 1.90 & 1.50 & 1.90 & 1.50 & $\mathbf{6}$ \\
\hline Liver & 1.20 & 4.10 & 4.30 & 3.80 & 4.20 & 3.50 \\
Flesh & 4.40 & &
\end{tabular}

Abdelhamid et al. (1990 and 1995b) found that feeding animals the mycotoxin contaminated foods increased their liver and muscles' content of water. Moreover, Abdelhamid et al. (2002b) noticed that feeding mycotoxin-contaminated diets increased body content of fat and ash but reduced its dry matter and protein percentages in the experimental animals. Dietary ginger inclusion alleviated aflatoxicosis symptoms, since it improved growth performance and survival rate, food and protein utilization, internal organs indices, carcass composition and residues of AFB1 (ppb) in the whole body of fish and the tested parameters of blood haematology and biochemistry of the experimented fish comparing with the worst values of these parameters by the aflatoixcated fish. Principally, prevention of ochratoxigenic fungi via medical herbs, spices, organic acids and salts (Abdelhamid et al., 1985; Romero et al., 2010) and essential oils (Mohamed et al., 2012) as well as good agricultural procedures (Abdelhamid, 1992) is more better than treating (curing) the OTA toxicity (Abdelhamid, 1993 and 1999).

Generally, Abdelhamid et al. (1998) found that autoclaving can reduce OTA by $11.3-27.7 \%$.Srour (2004) proved that Biogen ${ }^{\circledR}$ (including garlic) can improve the negative effects of OTA on Nile tilapia. Moreover, Yegani et al. (2005) referred to the good storage (drying, aeration, moving, sanitation, cleaning, minimizing mechanical damage, fungicides, fumigation, insecticides, protection against birds and rodents) of crops besides separation of contaminated parts, and using different means (physical, biological, and chemical) of treating the contaminated commodities and finally dilution and using adsorbents. Also, AbdelGalil (2005) found that dietary addition of garlic or cabbage meals $(5 \mathrm{~g} / \mathrm{kg})$ to OTA improved the biochemical parameters regarding liver and kidney functions. Moreover, Abde-Wahhab et al. (2005) proved that melatonin counteracts oxidative stress in rats fed the OTA contaminated diet.

\section{Histopathological examination}

Cross section in the liver of rat in (control, garlic and marjoram group) showing normal histological structure of the hepatic lobules, naturally hepatocyte arrangements $(\mathrm{H})$ with intact blood sinusoids (s) and normal central hepatic vein $(\mathrm{CV})$. Cross section in liver of rat treated with ochratoxin showing various pathological changes, including eruption of the lining epithelial squamous cells and dilatation of the central vein, atrophy in hepatocytes, hepatocellular degenerated (necrosis), abnormal arrangement and dilation of blood sinusoid. Cross section of liver in rat treated by ochratoxin with (garlic or marjoram) showing slight improvement in hepatic injuries and atrophy in some lining epithelial cells of central vein and hepatocytes (Fig. 2). The histological examination of portal area of liver in rat fed (control, garlic and marjoram) diet showing normal histological structure of the portal vein, hepatic artery and bile duct. Treating rat diets with ochratoxin caused some histopathological alterations including dilation and congestion of portal vein.

Addition of garlic or marjoram to the diet contaminated with ochratoxin enhanced portal area (Fig. 3). Cross section in the kidney of rat in (control, garlic and marjoram) group showing normal architecture of glomerulus (G) and convoluted renal tubules (T) within the cortical layer of the kidney. Cross section in the kidney of rat treated with ochratoxin showing glomerulus degeneration and atrophy in capillaries of glomerulus, congestion of blood vessels between the renal tubules and degeneration in the lining epithelial cells of renal tubules. Cross section in the kidney of rat treated with ochratoxin and (garlic or marjoram) showing reduction of incidence atrophy of glomerulus and interstitial matrix and necrosis in renal tubules (Fig. 4). Cross section in the spleen of rat in (control, garlic and marjoram) group showing normal white pulp (WP), red pulp (RP) and central arteriole (CA). Microscopic section in the spleen of rat treated with ochratoxin showing mild congestion of the red pulp and blood vessels with increase thickness of the muscular layer of congested follicles. Histological examination of spleen in rat treated by ochratoxin with garlic showing somewhat normal histology, so revealed more expanded white pulp on the account of red pulp. On the contrary the spleen in rat treated by ochratoxin with marjoram showed somewhat normal histology, so revealed more expanded red pulp on the account of white pulp (Fig. 5). 

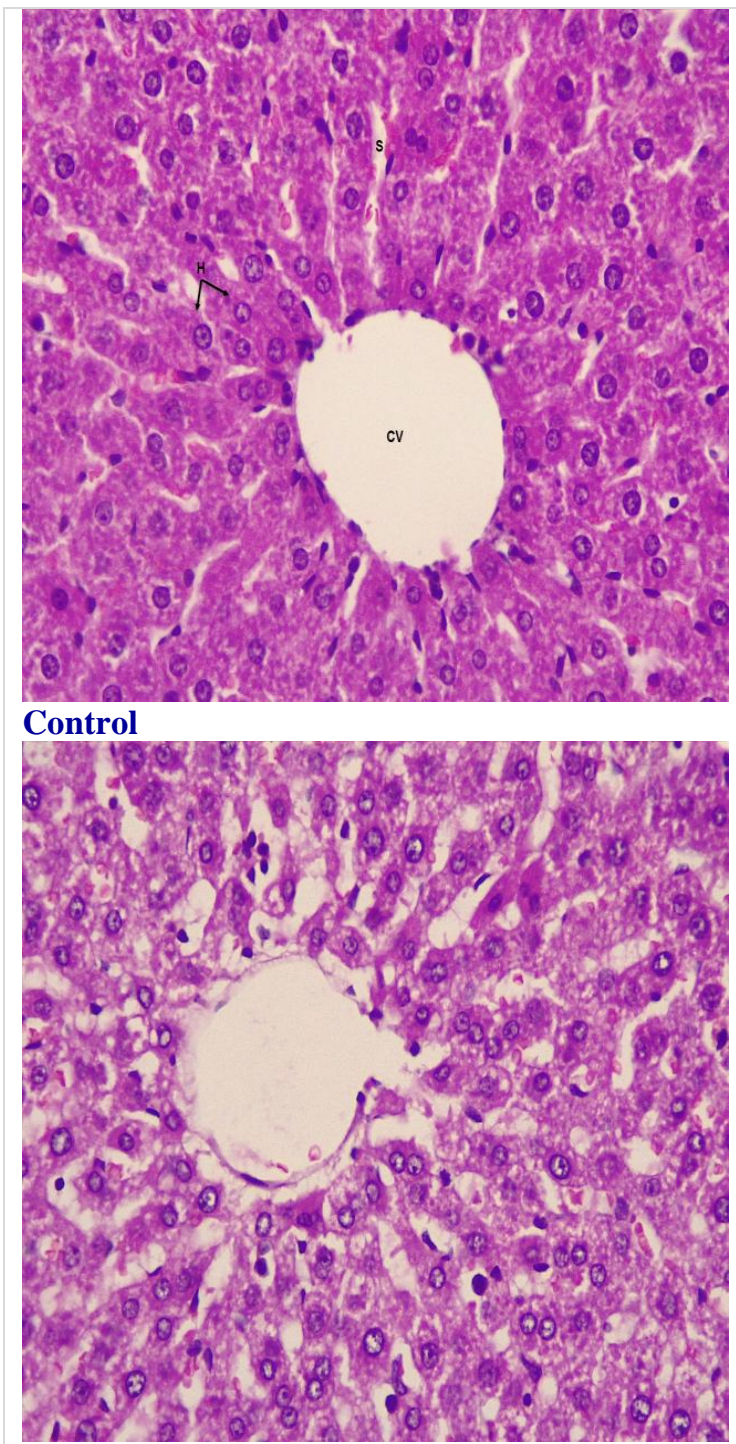

\section{Ochratoxin + Garlic}

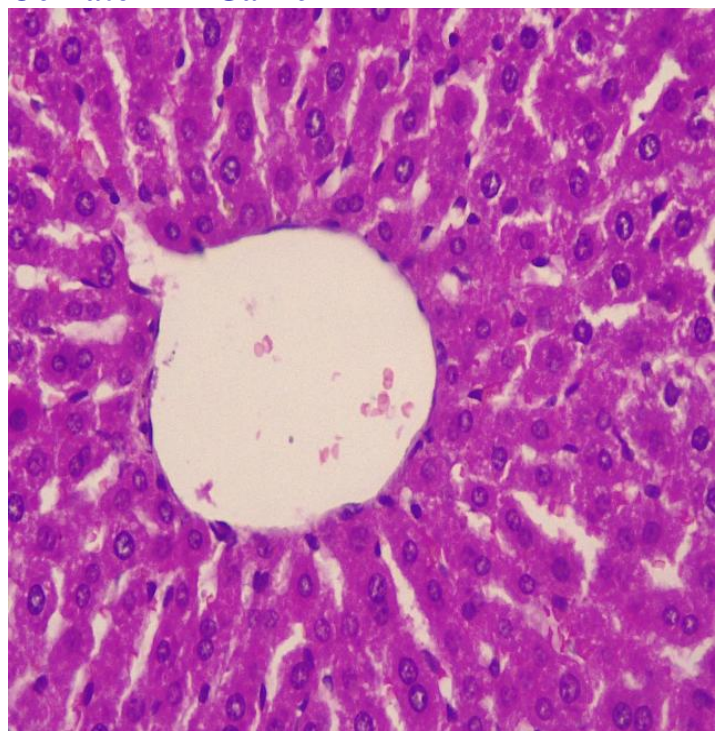

Garlic

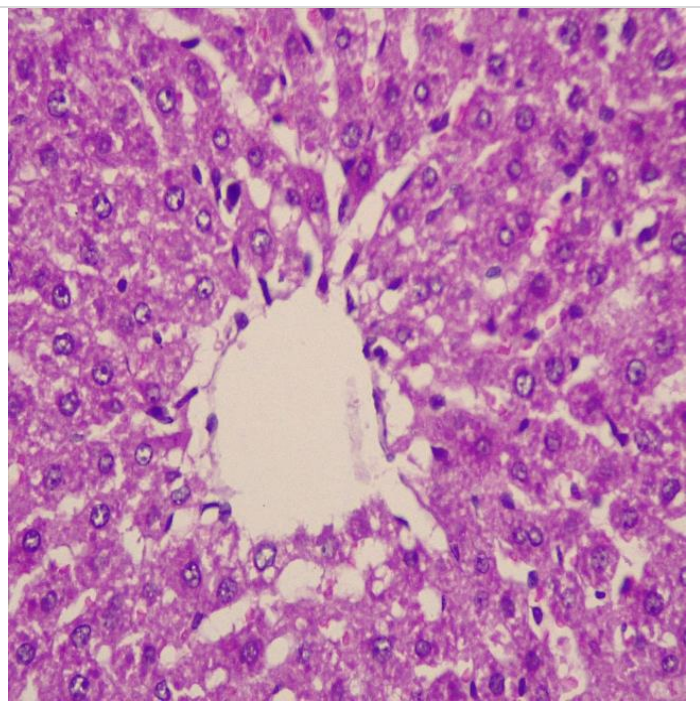

\section{Ochratoxin}

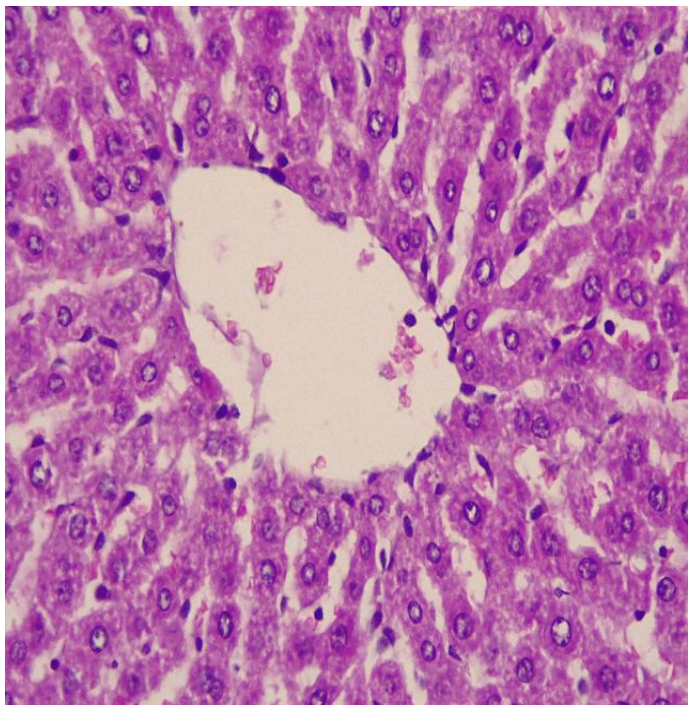

\section{Ochratoxin + Marjoram}

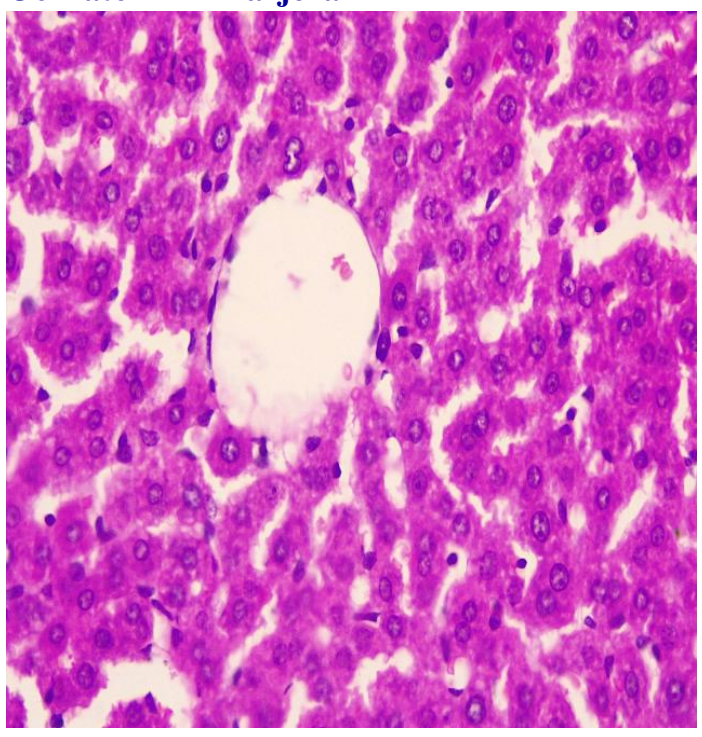

Marjoram

Fig. 2: Cross section in the liver of rat (H and $\mathrm{E} 400 \mathrm{x})$. 


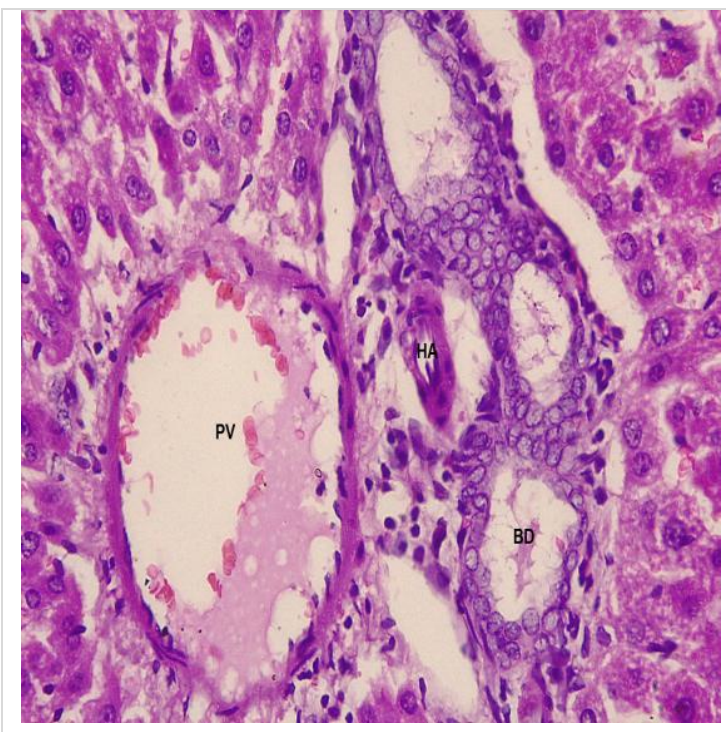

\section{Control}

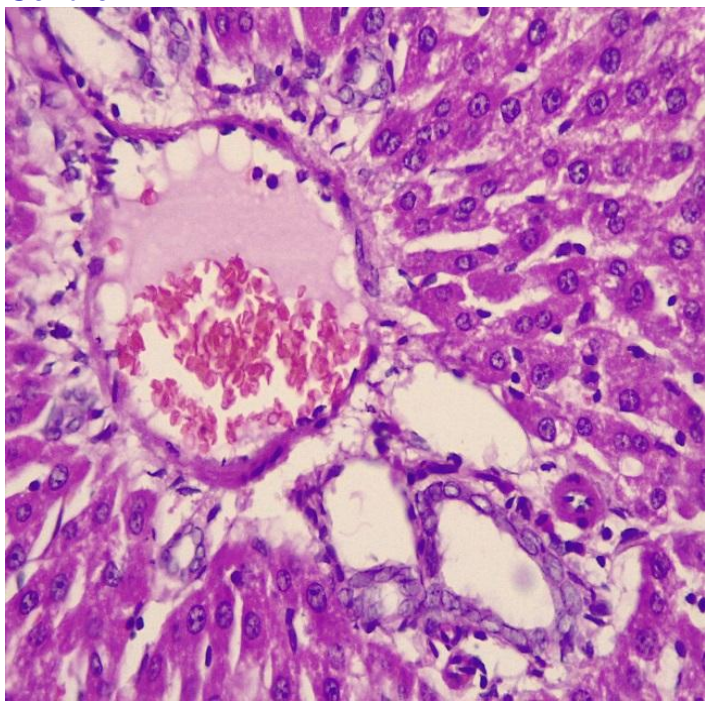

\section{Ochratoxin + Garlic}

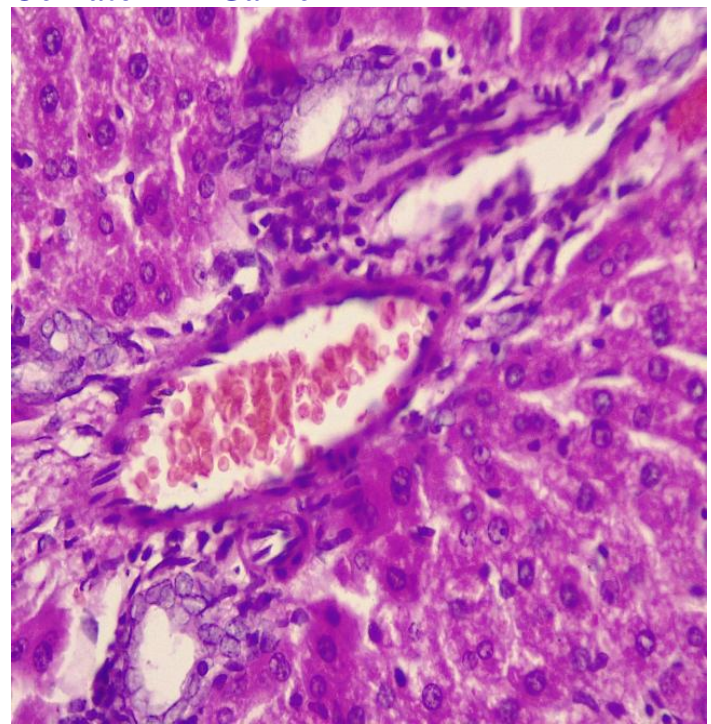

Garlic

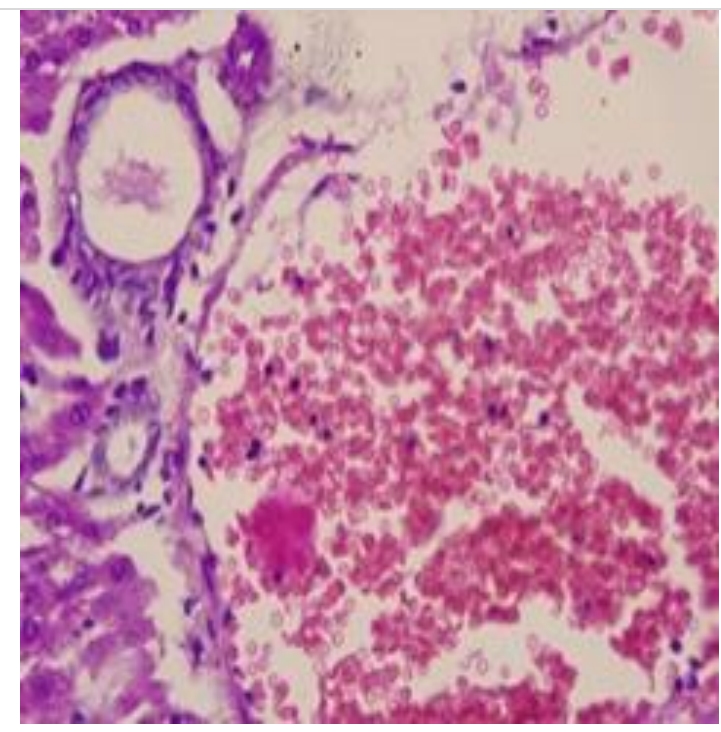

\section{Ochratoxin}
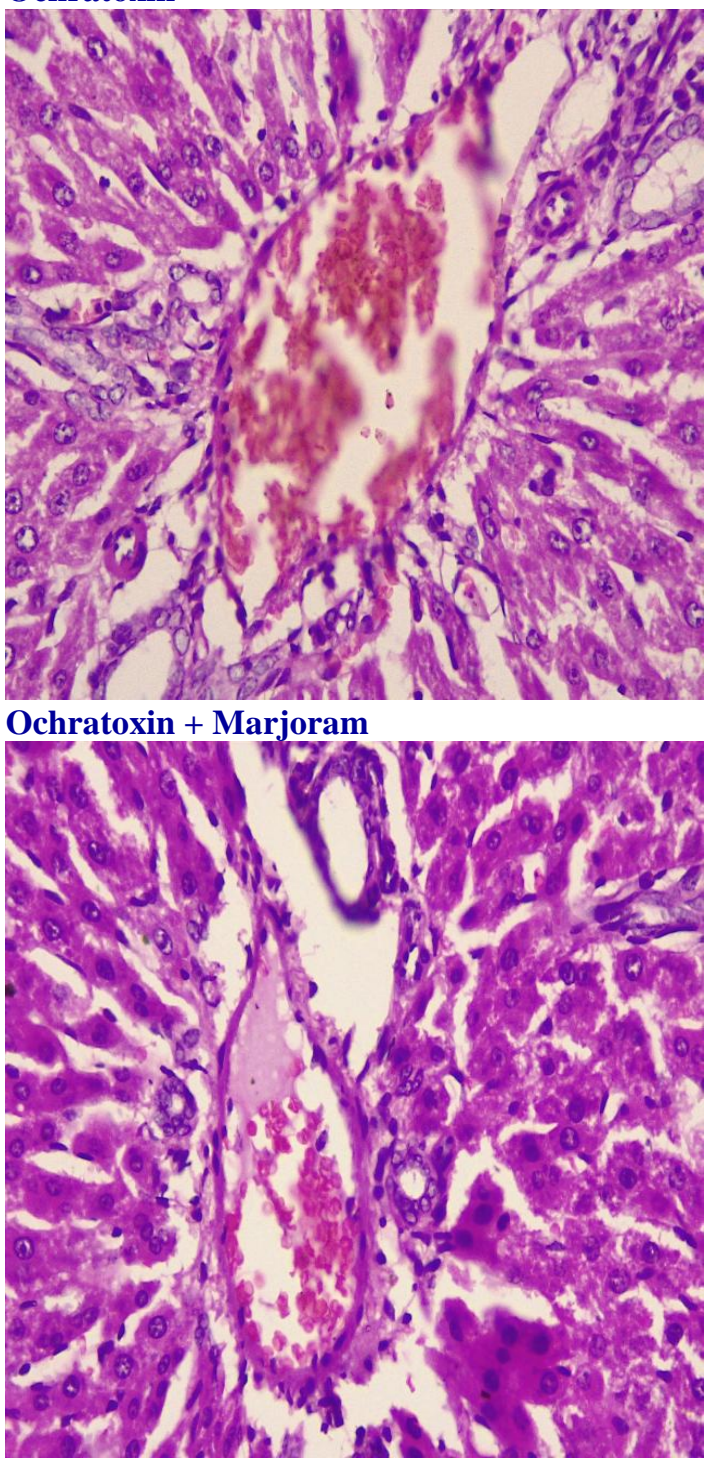

Marjoram

Fig. 3: Showing the histological examination of portal area of liver in rat (H \& E 400x). 


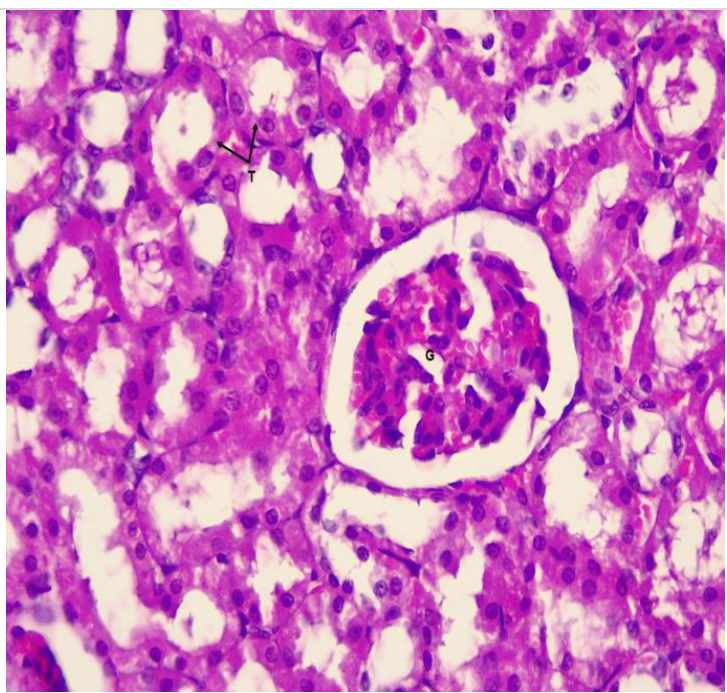

\section{Control}

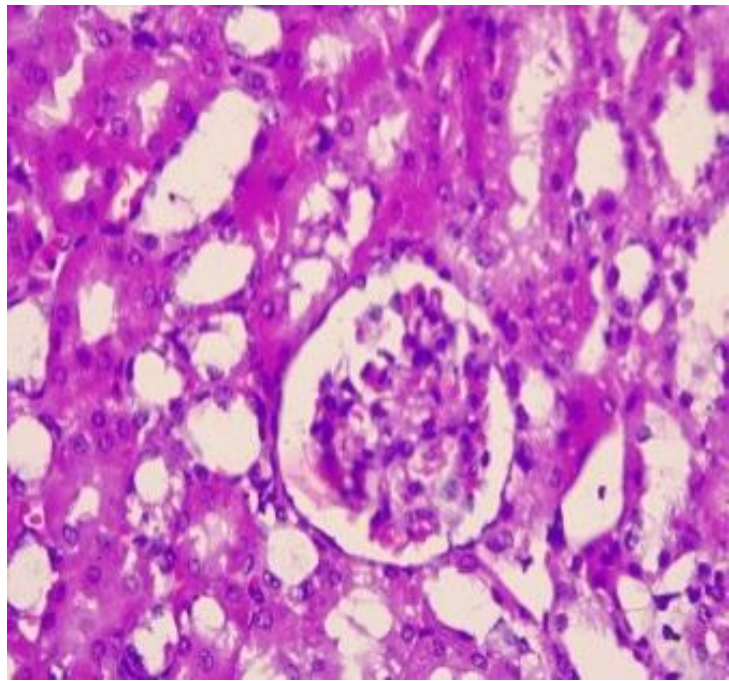

\section{Ochratoxin + Garlic}

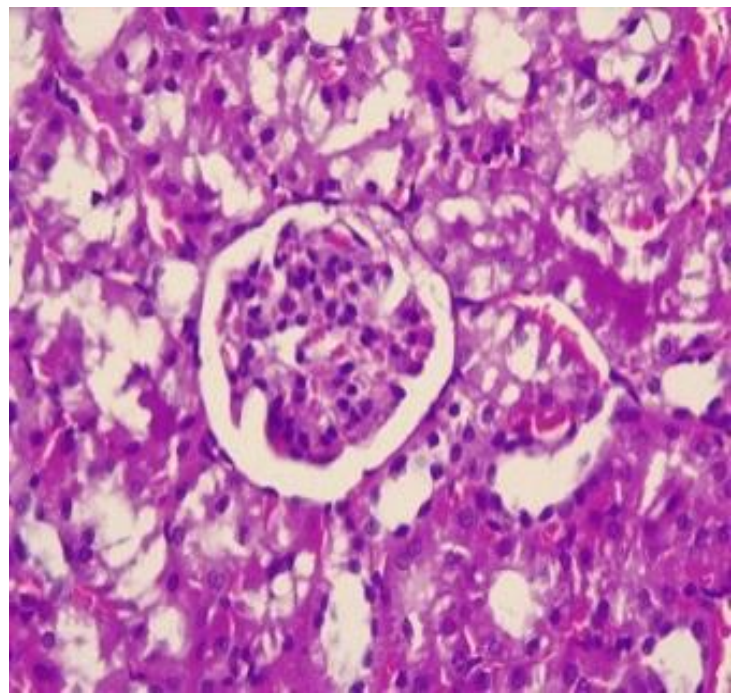

Garlic

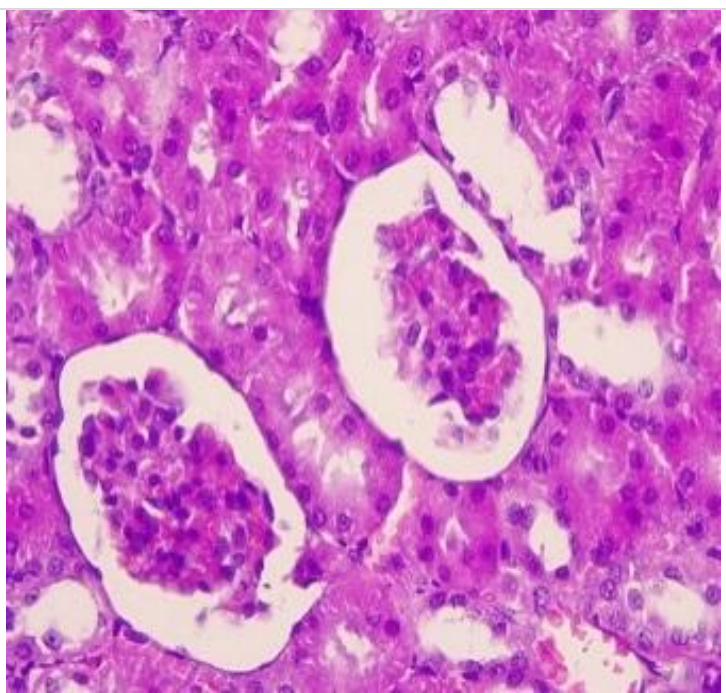

Ochratoxin

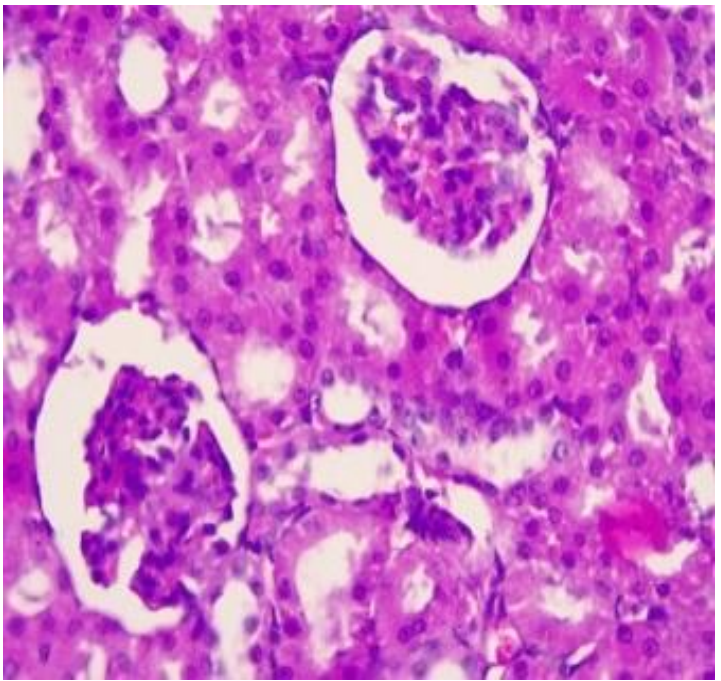

Ochratoxin + Marjoram

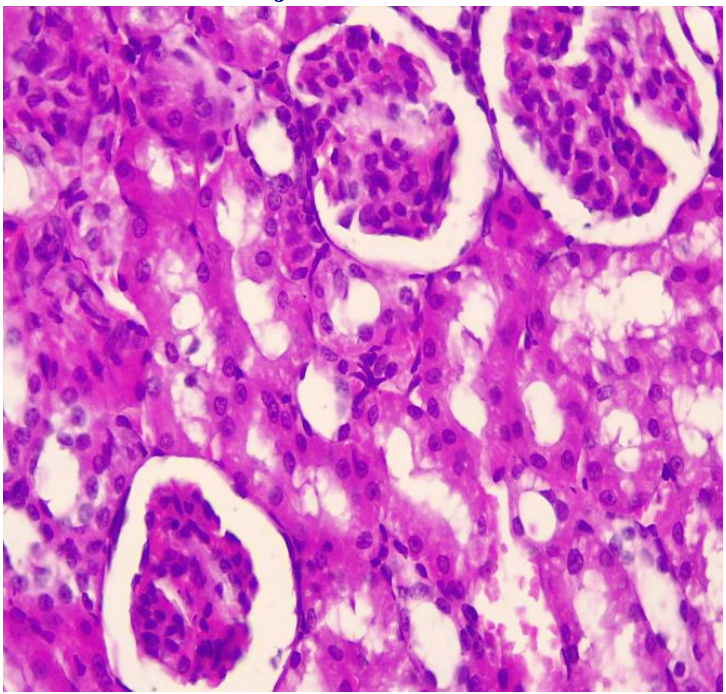

Marjoram

Fig. 4: Cross section in the kidney of rat (H \& E 400x). 


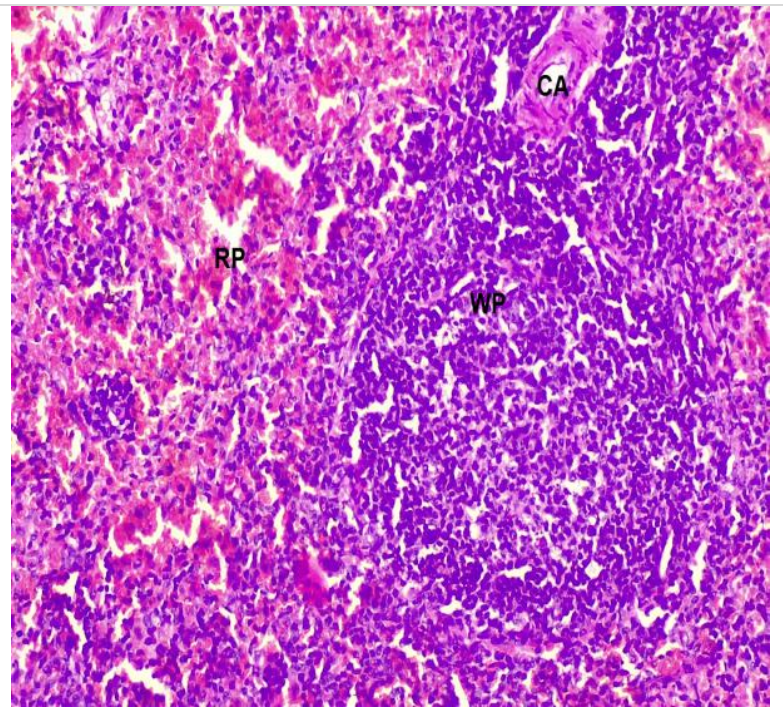

\section{Control}

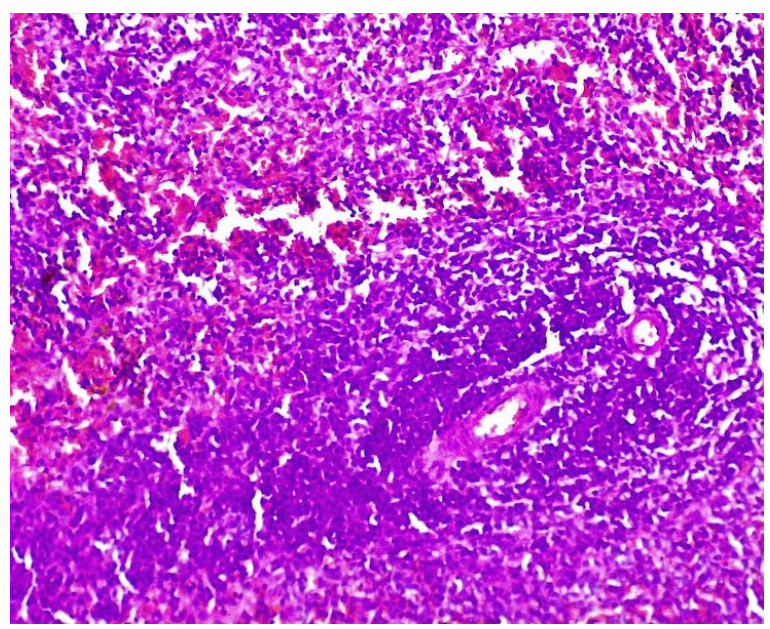

\section{Ochratoxin + Garlic}

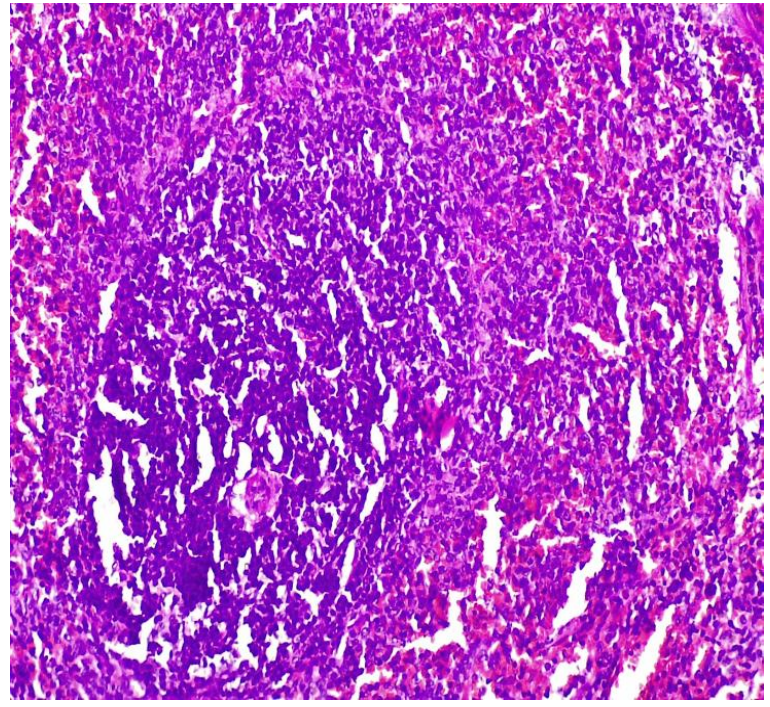

Garlic

Fig. 5: Cross section in the spleen of rat (H \& E 200x).

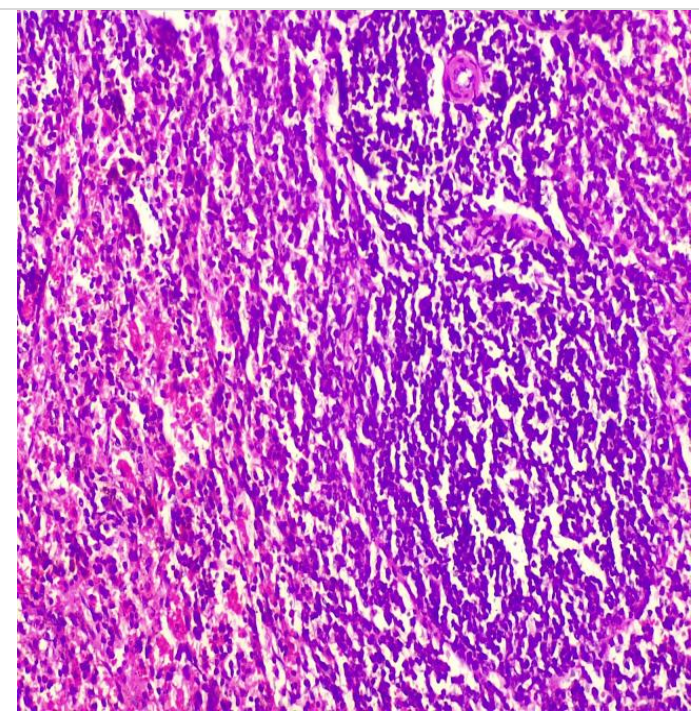

\section{Ochratoxin}

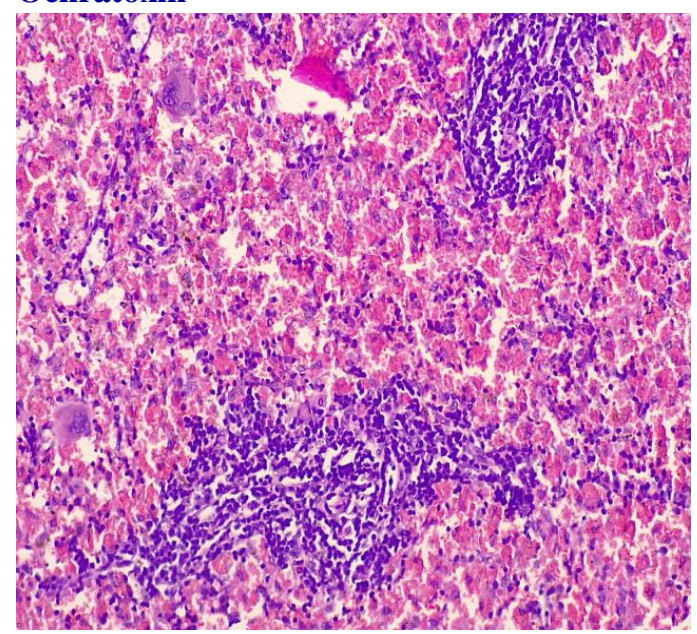

Ochratoxin + Marjoram

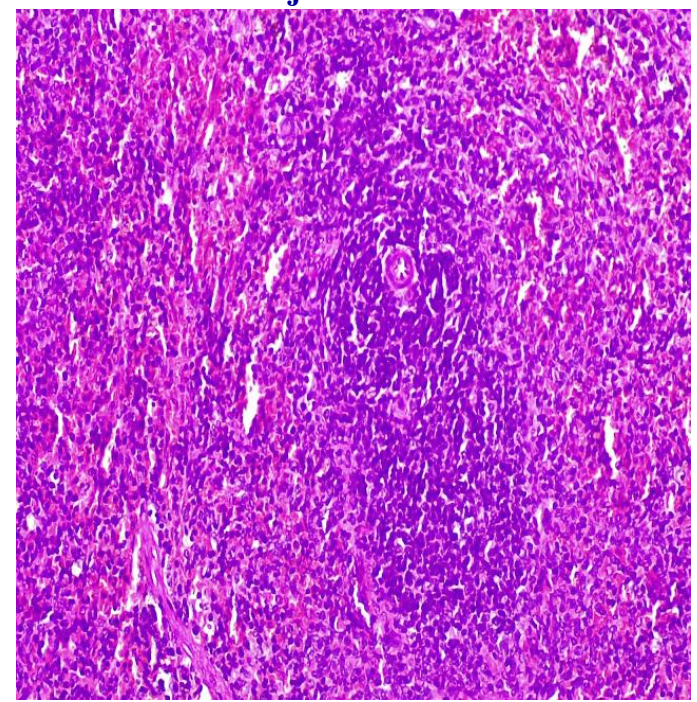

Marjoram

A. M. Abdelhamid et al. (2016) / Further Study on Toxicity of the Permissible (Very Low) Level of Ochratoxin A with and without Essential Oils on Rats 
Kidney is the major site of OTA-induced toxicity (Abdelhamid et al., 1999a and 1999b), where it acts principally on the middle and terminal segments of the proximal convoluted tubules (Jung and Endou, 1989). OTA has been shown to be nephrotoxic in all monogastric species tested, although there are species differences in sensitivity to nephrotoxic effects (Krogh et al., 1974 and 1976). OTA has also been shown to reduce the glomerular filtration rate (Stoev et al., 2002) and to affect $\mathrm{pH}$ homeostasis in the vasa recta, proximal tubules, distal tubules and collecting ducts within the kidney (Kuramochi et al., 1997a and b). Rodents treated with OTA, karyomegaly, reflected nephrosis and eosinophilia of the nephron tubules, granular and vacuolar degeneration of the tubular epithelial cells and interstitial fibrosis and thickening of the tubular basement membrane in histopathological examination of the kidney (Dortant et al., 2001 and Stoev et al., 2002). In addition to being a nephrotoxin, animal studies indicate that OTA is a liver toxin, an immune suppressant, a potent teratogen, and a carcinogen. OTA is believed to be responsible for a porcine nephropathy that has been studied intensively in the Scandinavian countries. There has been speculation that OTA is involved in a human disease called endemic Balkan nephropathy. It has also been hypothesized that OTA might be a risk factor for testicular cancer (Bennett and Klich, 2003). Abdelhamid et al. (1990 and 1992b) and Kandil et al. (1991) found that feeding animals the mycotoxin contaminated foods led to pathological findings, particularly in liver, heart, kidney, and spleen. The changes include hepatic round cell infiltration, irregularities of lobular plats, focal necrosis and periportal fibrosis.

In addition, Abdelhamid et al. (1999b) reported histological alterations in liver included congestion of the central vein, cellular infiltration, and nodular hyperplasia and vacuolization of the hepatocytes in acute-ochratoxicrabbits. Also, the kidneys of these acute-ochratoxicrabbits suffered from hyalinization and degeneration of glomeruli with tubular cell necrosis and degeneration of the proximal and distal tubules. Similar to OTA, another nephritic mycotoxin; i.e. oxalic acid, led histological findings included mild congestion of the portal vein in the portal tract, whereas the kidneys showed a degeneration of the glomeruli, polymorphonuclear leucocytes infiltration, and interstitial nephritis of rabbits (Abdelhamid and Saleh, 2000). Ascorbic acid content was reported to be very high in green garlic. Garlic, has biological activities that can have medically important effects. Garlic has been used as an excellent carminative, a nerve tonic and an antiseptic agent. Its properties include cholesterol lowering, garlic significantly lowers blood pressure, and garlic has an influence on platelet aggregation, an important factor in cardiovascular disease. It also has an effect on blood coagulation and fibrinolytic activity which are factors in the development of thrombosis. It reduced risk of stomach cancer as it has been identified as inhibiting tumor growth. Garlic also has antioxidant properties which are helpful in preventing cancer and cardiovascular disease (Rahman and Lowe, 2006 and Gardner et al., 2007). Marjoram acts as antioxidant (Potty and Kumar, 2001; El-Ghorab et al., 2004). Marjoram is useful for pituitary gland, liver, colon, and pancreas (Ibrahim, 2013).

\section{Conclusion}

In conclusion, to completely eliminate the presence of mycotoxins (MT) in the raw food material is not possible; therefore, in many countries for the most studied MT there were legally established Maximum Permissible Concentration (MPC) of toxins, below which the raw materials or foods can be used without restrictions. In animals consuming feeds containing toxin below the MPC, the last is inactivated by xenobiotic metabolizing system and, therefore, has no apparent effect on the organism. Xenobiotics or alien to the body substances include mycotoxins (Sheweita, 2000; Galtier et al., 2008). Increasing knowledge will help elucidate the influence of MT. Yet, the very low ochratoxin A level is still harmful and essential oils used are not a treating method to overcome its toxicity symptoms. We need more research efforts in this field.

\section{Conflict of interest statement}

Authors declare that they have no conflict of interest.

\section{References}

AOAC, 2000. Assocation of Official Analysis of Chemicals, Arlington, VA. $15^{\text {th }}$ Edn. Washington. D.C., USA.

Abd El-Hakim, A. E., 2008. Effect of type of diet on productive and reproductive performance of Nile tilapia reared on commercial scale. Ph. D. Thesis, Fac. of Agric., Fayoum Univ., Egypt.

Abdel-Galil, M.M., 2005. Dietary garlic and cabbage protects against ochratoxin A toxicity in rats. Sc. J. Az. Med. Fac. (Girls). 26 (2), 659-671.

Abdelhamid, A. M., 1990. Occurrence of some mycotoxins (aflatoxin, ochratoxin-A, citrinin, zearalenone and vomitoxin) in various Egyptian feeds. Arch. Anim. Nutr. 40, 647-664. 
Abdelhamid, A. M., 2000. Fungi and Mycotoxins. $1^{\text {st }}$ Edn. Dar Anashr for Universities, Cairo, Egypt. Deposit No. 13738/1997 - ISBN 977-5526180-9.

Abdelhamid, A. M., 1983. Detection of ochratoxin-A in the Egyptian food and feedstuffs. In: Proceedings of the $1^{\text {st }}$ African Conference of Food and Technology, Cairo, Egypt. pp.604-613.

Abdelhamid, A. M., 1993. Mycotoxins in local foods and feeds. The $4^{\text {th }}$ Symposium of Food Pollution, Assiut Univ., Egypt. 15-16 November. pp.46-57.

Abdelhamid, A. M., 2005. Mycotoxicoses in fish with special emphasis on the Egyptian situation. Proc. $12^{\text {th }}$ Inter. Con. 19-24 Nov., Al-Hodeidah Univ., Yemen, J. Union Arab Biol. Cairo, Egypt. 24A (Zoology), 185-214.

Abdelhamid, A. M., Saleh, M. R. M., 1996. Are aflatoxin and ochratoxin endemic mycotoxins in Egypt? Proc. Food Borne Contamination and Egyptian's Health Conference, Mansoura Univ. 26-27 Nov. pp.51-59.

Abdelhamid, A. M., Saleh, M. R. M., 2000. Effect of graded levels of dietary oxalic acid on growth performance, physiological responses and histological alterations in New Zealand White rabbits. J. Agric. Sci., Mansoura Univ. 25, 4891-4903.

Abdelhamid, A. M., Arief, H. S. M., El-Keraby, F. E., Dorra, T. M., 1995a. Effect of some dietary supplements to aflatoxic diets of chickens. II. On the tissues analysis. J. Agric. Sci. Mansoura Univ. 20, 3227-3250.

Abdelhamid, A. M., Dorra, T. M. Mansy, S. E., Sallam, A. E., 1994. Effect of raising dietary protein, amino acids and/or energy levels as an attempt to alleviate severity of the chronic aflatoxicosis by broiler chicks. II- On the biochemical characteristics. Arch. Anim. Nutr. 46, 347355 .

Abdelhamid, A. M., El-Ayoty, S. A., Elsaadany, H. H., 1992a. The influence of contamination with separate mycotoxins (aflatoxins, ochratoxin A, citrinin, patulin, penicillic acid or sterigmatocystin) on the dry matter and organic matter digestibilities of some roughage (Berseem hay and wheat straw) using in vitro rumen fermentation, Arch. Anim. Nutr. 42, 179-185.

Abdelhamid, A. M., El-Mansoury, A. M., Osman, A. I., ElAzab, S. M., 1999a. Mycotoxins as causative for human food poisoning under Egyptian conditions. J. Agric. Sci. Mansoura Univ. 24, 2751-2757.

Abdelhamid, A. M., El-Melegy, Kh. M., Ahmed, A. M., 2005. Possibility of alleviating foodborne aflatoxicosis effects on performance and biochemistry of male albino white rats. J. Agric. Sci. Mansoura Univ. 30, 833-849.

Abdelhamid, A. M., El-Shawaf, I., Elayoty, S.A., Ali, M.M., Gamil, I., 1990. Effect of low level of dietary aflatoxins on baladi rabbits. Arch. Anim. Nutr. 40, 517-537.

Abdelhamid, A. M., Kandil, W. M., Arief, H. S. M., Dorra, T., M., 1995b. Effect of some dietary supplements to aflatoxic diets of chickens. III. On the histopathology. J. Agric. Sci. Mansoura Univ. 20, 3251-3259.

Abdelhamid, A. M., Kelada, I.P., Ali, M.M., El-Ayoty, S. A., 1992b. Influence of zearalenone on some metabolic, physiological and pathological aspects of female rabbits at two different ages. Arch. Anim. Nutr. 42, 63-70.

Abdelhamid, A. M., Khalil, F. F., Ragab, M. A., 1996. Survey of aflatoxin and ochratoxin occurrence in some local feeds and foods. Proceeding of Conference on Food Borne Contamination and Egyptian's Health, Mansoura Univ., Egypt, Nov. 26-27. pp.43-50.

Abdelhamid, A. M., Khalil, F. F. M., El-Barbary, M. I., Zaki, V. H., Husien, H.S., 2002a. Feeding Nile tilapia on Biogen ${ }^{\circledR}$ to detoxify aflatoxic diets. Proc. $1^{\text {st }}$ Ann. Sc. Conf. Anim. \& Fish Prod., Mansoura Fac. Agric., Egypt. Sept. 24 \& 25. pp. 207-230.

Abdelhamid, A. M., Magouz, F. I., Salem, M. F. E., Mohamed, A. A., Mohsen, M. K., 2002b. Effect of dietary graded levels of aflatoxin B1 on growth performance and biochemical, chromosomal and histological behavior of Nile tilapia, Oreochromis niloticus. Proc. $1^{\text {st }}$ Ann. Sc. Conf. Anim. \& Fish Prod., Mansoura Fac. Agric., Egypt. Sept. 24 \& 25. pp.231-250.

Abdelhamid, A. M., El-Nashar, E.M., Saleh, M.R.M., 1999b. Effect of subacute ochratoxicosis- A by rabbits. Proc. $15^{\text {th }}$ Ann. Conf. Egypt. Soc. Toxicol. Alex., Egypt. Oct. 6-7, Vol. 1, pp.71-85.

Abdelhamid, A.M., 1989. Contamination of feedstuffs with mycotoxins and consequences of these contaminants. Animal Nutrition Symposium, Assiut, Egypt, Nov. pp.2975.

Abdelhamid, A.M., 1992. Lights on mycotoxins and mycotoxicoses in the field of animal production. The $32^{\text {nd }}$ Week of Science, 7-13 Nov., Damascus, Syria, 17p.

Abdelhamid, A.M., 1999. Foodborne mycotoxicosis by rabbits. Symposium of rabbits' industry and production development in Damitta governorate, Egypt, 20 June, 2 p.

Abdelhamid, A.M., 2004. Aquafeed quality: mycotoxins and mycotoxicoses in fish. A lecture given on the $21^{\text {st }}$ of June at World Fish Center, Abbasa, Abo Hamad, Sharqia, Egypt, 21p.

Abdelhamid, A.M., Sadik, E.A., Fayzalla, E.A., 1985. Preserving power of some additives against fungal invasion and mycotoxin production in stored-crushed-corn containing different levels of moisture. Acta Phytopathol. Academ. Scientiar. Hungar. 20(4-4), 309-320.

Abdelhamid, A.M., Khalil, F.F., Ragab, M.A., 1998. Problem of mycotoxins in fish production. Egypt J. Nutr. Feeds 1(1), 63-71.

Abdelhamid, A.M., Mehrim, A.I., Seden, M.E.A., Zenhom, O.A., 2014. Effect of different sources and levels of some dietary biological additives on: III- body composition and muscular histometric characteristics of Nile tilapia fish. Egypt. J. Aquat. Biol. Fish. 18(1), 13-24.

Abdelhamid, A.M., Refaey, M.M.A., Seden, M.E.A., Zenhom, O.A., 2013. Effect of different sources and levels of some dietary biological additives on: IV- Immunity and haematology of Nile tilapia fish. Egypt. J. Aquat. Biol. Fish. 18(1), 49-60.

Abdelhamid. A. M., Sallam, A. E., Abd Allah, G. A., ElSamra, S. H., 2002c. Effect of feeding male rats on 
aflatoxic diets without or with medicinal herbs (thyme, safflower, ginger, black cumin, and/or garlic). Proc. $2^{\text {nd }}$ Conf. on Food borne Contamination and Egyptian's Health, April 23-24, Mansoura Fac. Agric., Egypt. pp.99121.

Abdel-Khalek, A.E., Abdelhamid, A.M., Mehrez, A.F., ElSawy, I., 2012. Growth performance, digestibility coefficients, blood parameters and carcass traits of rabbits fed biologically treated diets. J. Anim. Poultry Prod. Mansoura Univ. 3(5), 227-239.

Abde-Wahhab, M.A., Abdel-Galil, M.M., El-Lithey, M., 2005. Melatonin counteracts oxidative stress in rats fed an ochratoxin A contaminated diet. J. Pineal Res. 38, 130135.

Abu El-Hamd, M. A., Sheteifa, M. A. M., Ragab, A. A., 2013. Effect of ascorbic acid on performance and reproductive performance of does New Zealand white rabbit. J. Anim. Poultry Prod. Mansoura Univ. 4(9), 549-559.

Algedawy, S. A., Soliman, K. K., Elashmawy, I.M., El-Sayed, Y. S., 2011. Effect of commercial probiotic and exogenous enzymes on the growth performance, immune response, and hemato-biochemical parameters of broiler chickens. The $4^{\text {th }}$ Sci. Conf. of Animal Wealth Research in the Middle East \& North Africa. p.23 (Abstract).

Ali, M. M., Abdelhamid, A. M., Elansary, E., Raya, A. H., 1984. The effect of ochratoxin-A on some metabolic and physiological aspects in pigeons. Assiut J. Agric. Sci. 15, 119-129.

Bendele, A. M., Carlton, W. W., Krogh, P., Lillehoj, E. B., 1985. Ochratoxin A carcinogenesis in the (C57BL/6J X C3H)F1 mouse. J. Natl. Cancer Inst. 75, 733-742.

Bennett, J. W., Klich, M., 2003. Mycotoxins. Clin Microbiol Rev. 16(3), 497-516.

Berndt, W. O., Hayes, A. W., 1979. In vivo and in vitro changes in renal function caused by ochratoxin $\mathrm{A}$ in the rat. Toxicol. 12, 5-17.

Binder, E.M., 2006. Managing the risk of mycotoxins in modern feed production. Anim. Feed Sci. Technol. 133, 149-166.

Biro, K., Barna-Vetro, I., Pecsi, T., Szabo, E., Winkler, G., Fink-Gremmels, J., Solti, L., 2003. Evaluation of spermatological parameters in ochratoxin A-challenged boars. Theriogenol. 60, 199-207.

Borutova, R., 2015. Dairy producers robbed by mycotoxins every day. MycotoxinsTechnical Articles / Mycotoxins Contaminations. Available at: http://en.engormix.com/ MA-mycotoxins/articles/dairy-producers-robbedmycotoxins-t3451/p0.htm

Broom, L., Harington, D., Konstanti, K., 2016. Natural solutions: Organic acids and phytogenetics. Gut HealthOctober. p.20.

CAST (Council for Agricultural Science and Technology), 2003. Mycotoxins: Risks in plant, animal and human systems. Task Force Report No. 139, Ames.

Creppy, E. E., Roschenthaler, R., Dirheimer, G., 1984. Inhibition of protein synthesis in mice by ochratoxin A and its prevention by phenylalanine. Food Chem. Toxicol.
22, 883-886.

Donmez-Altuntas, H., Hamurcu, Z., Imamoglu, N., Liman, B. C., 2003. Effects of ochratoxin A on micronucleus frequency in human lymphocytes. Nährung. 47, 33-35.

Dortant, P. M., Peters-Volleberg, G. W., Van Loveren, H., Marquardt, R. R., Speijers, G. J., 2001. Age-related differences in the toxicity of ochratoxin $\mathrm{A}$ in female rats, Food Chem. Toxicol. 39, 55-65.

Duncan, D.B., 1955. Multiple ranges and multiple F-tests. Biometrics. 11, 1-42.

Dwivedi, P., Burns, R. B., 1984a. Pathology of ochratoxicosis A in young broiler chicks. Res. Vet. Sci. 36, 92-103.

Dwivedi, P., Burns, R. B., 1984b. Effect of ochratoxin A on immunoglobulins in broiler chicks. Res. Vet. Sci. 36, $117-$ 121.

El-Ghorab, A.H., Mansour, A.F., El-massry, K.F., 2004. Effect of extraction methods on the chemical composition and antioxidant activity of Egyptian marjoram (Majorana hortensis Moench). Flav. Fragr. J. 19(1), 54-61.

El-Medany, Sh.A., El-Reffaei, W.H., Nada, S.A., 2013. Effect of different oils on growth performance and carcass traits in growing rabbits. J. Anim. Poultry Prod. Mansoura Univ. 4(12), 733-745.

Galtier, P., Meissonnier, G., Joelle Laffitte, Isabelle, P. Oswald, Loisea N., 2008. Molecular interactions between mycotoxins and liver enzymes involved in drug metabolism in rodents and farm animals. Krmiva. 50(4), 205-213.

Gardner, C. D., Lawson, L. D., Block, E., Chatterjee, L. M., Kiazand, A., Balise, R. R., Kraemer, H. C., 2007. Effect of raw garlic vs commercial garlic supplements on plasma lipid concentrations in adults with moderate hypercholesterolemia: A randomized clinical trial. Arch. Internal Med. 167(4), 346-353.

Gharbi, A., Trillon, O., Betbeder, A. M., Counord, J., Gauret, M. F., Pfohl-Leszkowicz, A., Dirheimer, G., Creppy, E. E., 1993. Some effects of ochratoxin A, a mycotoxin contaminating feeds and food, on rat testis, Toxicol. 83, 918.

Hatey, F., Galtier, P., 1977. Short term toxicity of ochratoxin A: Some biochemical lesions in the rat. Ann. Rech. Vet. 8, 7-12.

Ibrahim, M., 2013. Marjoram. National Research Center, Cairo, Egypt. Available at: http://en.engormix.com/

Jung, K. Y., Endou, H., 1989. Nephrotoxicity assessment by measuring cellular ATP content. II. Intranephron site of ochratoxin A nephrotoxicity. Toxicol. Appl. Pharmacol. 100, 383-390.

Kandil, W. M., Sirag, S. M., Abdelhamid, A. M., Dorra, T. M., 1991. Histopathological studies on mycotoxicoses in broiler chicks. Mansoura Med. J. 21, 193-204.

Kane, A., Creppy, E. E., Roschenthaler, R., Dirheimer, G., 1986. Changes in urinary and renal tubular enzymes caused by subchronic administration of ochratoxin $\mathrm{A}$ in rats. Toxicol. 42, 233-243.

Kanisawa, M., 1984. Synergistic effect of citrinin on hepatorenal carcinogenesis of OA in mice. In Toxigenic 
Fungi - Their Toxins and Health Hazard (Eds.: Kurata, H., Ueno, Y.). Elsevier, Tokyo. pp.245-254.

Kanisawa, M., Suzuki, S., 1978. Induction of renal and hepatic tumors in mice by ochratoxin A, a mycotoxin. Gann. 69, 599-600.

Kellerman, T.S., Marasas, W.F.O., Thiel, P.G., Gelderblom, W.C.A, Cawood, M., Coetzer, J.A.W., 1990. Leucoencephalomalacia in two horses induced by dosing of fumonisin B1, Ondersterpoort J. Vet. Res. 57, 269-275.

Koolhass, J.M., 2001. The laboratory rat. Chapter 19 In: The UFAW Handbook on The Care and Management of Laboratory Animals $7^{\text {th }}$ Edn., Vol. 1: Terrestrial Vertebrates (Eds.: Poole, T., English, P.). Blackwell Science, Oxford, England.

Krogh, P., Axelsen, N. H., Eling, F., Gyrd-Hansen, N., Hald, B., Hyldgard-Jensen, J., Larsen, A. E., Madsen, A., Mortensen, H. P., Möller, T., Petersen, O. K., Ravnskov, V., Rostgaard, M., Alund, O., 1974. Experimental porcine nephropathy. Acta Pathol. Microbiol. Scandinavia, Section A (Suppl. No. 246), 1-21.

Krogh, P., Elling, F., Hald, B., Jvilling, B., Petersen, V. E., Skad-hauge, E., Svenden, C. K., 1976. Experimental porcine nephropathy: changes of renal function and structure perorally induced by crystalline ochratoxin A. Acta Pathol. Microbiol. Scandinavia, Section A. 84, 429434.

Kuramochi, G., Gekle, M., Silbernagl, S., 1997a. Derangement of $\mathrm{pH}$ homeostasis in the renal papilla: Ochratoxin A increases $\mathrm{pH}$ in vasa recta blood. Nephron. 76, 472-476.

Kuramochi, G., Gekle, M., Silbernagl, S., 1997b. Ochratoxin A disturbs $\mathrm{pH}$ homeostasis in the kidney: Increases in $\mathrm{pH}$ and $\mathrm{HCO} 3-$ in the tubules and vasa recta. Pflugers Arch. 434, 392-397.

Kutsky, R.J., 1973. Handbook of Vitamins and Hormons. Van Nostrand Reinhold Company, New York.

Latner, A.L., 1975. Cantarow and Trumper Clinical Biochemistry. $7^{\text {th }}$ Edn. W.B. Saunders Company, London.

Luhe, A., Hildebrand, H., Bach, U., Dingermann, T., Ahr, H. J., 2003. A new approach to studying ochratoxin A (OTA)-induced nephrotoxicity: Expression profiling in vivo and in vitro employing cDNA microarrays. Toxicol. Sci. 73, 315-328.

Magouz, F.I., Eweedah, N.M., Salem, M.F.E., Amer, A.A., 2016. Detoxification of aflatoxin contaminated ration by chemical, biological and spice in Nile tilapia (Oreochromis niloticus) diets. J. Agric. Res. Kafrelsheikh Univ. (in press).

Mahmoud, K. I., Abdelhamid, A. M., Mandour, A., 1994. In vitro and in vivo comparative studies on the efficacy of some aflatoxin-detoxifying agents. Alex. J. Vet. Sci. 10, $39-47$.

Merck, E., 1976. Labordiagnostik in der Tiermedizin. Diagnostica Merck, Deutschland.

Mercola, J., 2016. Mercola's Herbal Oil List and Herbal Net (http://www.herbslist.net/).

Mohamed, S.R., Deabes, M.M., Abdel-Motaleb, N.M., Mohamed, S.S., Badr, A.N., Shaban, E.M., Khalil, A.F.,
2012. Antifungal activity of basil and mustard essential oils against spoilage toxigenic fungi in Egyptian pan bread and its economic evaluation. J. Appl. Sci. Res. 8(11), 5536-5542.

Muller, G., Rosner, H., Rohrmann, B., Erler, W., Geschwend, G., Grafe, U., Burkert, B., Moller, U., Diller, R., Sachse, K., Kohler, H., 2003. Effects of the mycotoxin ochratoxin A and some of its metabolites on the human cell line THP1. Toxicol. 184, 69-82.

National Toxicology Program, 1989. Technical report on the toxicology and carcinogenesis studies of ochratoxin A (CAS No. 303-47-9) in F344 rats (Gavage studies). NIH publication No. 89-2813, Research Triangle Park, NC, US Department of Health and Human Services, National Institutes of Health.

Potty, S.N., Kumar, V.K., 2001. Marjoram. Chapter 19 in: Handbook of Herbs and Spices (Ed.: Peter, K.V.). Woodhead Publishing Limited and CRC Press LLC, England/USA.

Rahman, K., Lowe, G.M., 2006. Garlic and cardiovascular disease: A critical review. J. Nutr. 136(3 Suppl.), 736S$740 \mathrm{~S}$.

Romero, S.M., Alberto, M.R., Vaamonde, G., 2010. Effect of gallic acid on Aspergillus carbonarius growth and ochratoxin A production. World Mycotoxin J. 3(1), 45-48.

Rupic, V., Liker, B., Muzic, S., Bogdanic, C., Balzer, I., 1978. Effect of ochratoxin A on lipid and protein levels in the blood of chickens. Arh. Hig. Rada. Toksikol. 29, 139-45.

Sadek, A.M.A., 2011. Studies in Feeding Rabbits. Ph.D. Thesis, Faculty of Agriculture, Al-Mansourah University.

Said, M.M.A., 2016. Effect of some medicinal herbs on rabbits performance. M. Sc. Thesis, Animal Production, Faculty of Agriculture, Zagazig University, Egypt.

SAS Institute, 2006. SAS User's Guide: Statistics. Version 8.2, SAS Institute Inc., Cary, NC.

Schaaf, G. J., Nijmeijer, S. M., Maas, R. F., Roestenberg, P., de Groene, E. M., Fink-Gremmels, J., 2002. The role of oxidative stress in the ochratoxin A-mediated toxicity in proximal tubular cells, Biochim. Biophys. Acta. 1588, 149-158.

Sheweita, S. A., 2000. Drug-metabolizing enzymes: Mechanisms and functions. Curr. Drug Metabol. 1, 107132.

Soliman, M.K., Abd El Moty, I., 1974. A Modern Approach to veterinary Clinical and Laboratory Diagnosis. The Scientific Book Centre, Cairo, Egypt, 747p.

Srour, T.M., 2004. Effect of ochratoxin-A with or without Biogen ${ }^{\circledR}$ on growth performance, feed utilization and carcass composition of Nile tilapia (Oreochromis niloticus) fingerlings. J. Agric. Sci. Mansoura Univ. 29, 51-61.

Stoev, S. D., Paskalev, M., MacDonald, S., Mantle, P. G., 2002. Experimental one year ochratoxin A toxicosis in pigs. Exp. Toxicol. Pathol. 53, 481-487.

Syriopoulos, K., Aumiller, T., Vinyeta, E., 2016. Using phytogenics to boost gut health in weaned piglets. Gut Health-October. pp.32-33. 
Szkudelska, K., Drzymała, H., Szkudelski, T., Bukowska, K., Nogowski, L., 2005. Lack of the effect of mycotoxinsaflatoxin B1 and ochratoxin A on some functions of rat adipocytes. Toxicol. In Vitro. 19, 771-777.

Tawfik, S.A, Ahmed, M.E., Saeta, E.I., El-Gazzar, O.B., 2005. Effect of adding chamomile flowers to aflatoxins containing diet on growth performance, rumen parameters and some blood components of growing lambs. $4^{\text {th }}$ Inter. Sci. Conf. Mansoura.

Thuvander, A., Breitholtz-Emanuelsson, A., Olsen, M., 1995. Effects of ochratoxin A on the mouse immune system after subchronic exposure. Food Chem. Toxicol. 33, 1005-1011.

Thuvander, A., Breitholtz-Emanuelsson, A., Brabencova, D., Gadhasson, I., 1996a. Prenatal exposure of Balb/c mice to ochratoxin A: Effects on the immune system in the offspring. Food Chem. Toxicol. 34, 547-554.

Thuvander, A., Funseth, E., Breitholtz-Emanuelsson, A., Hallen, I. P., Oskarsson, A., 1996b. Effects of ochratoxin A on the rat immune system after perinatal exposure, Nat. Toxins. 4, 141-147.

Varley, H., 1978. Practical Clinical Biochemistry. $4^{\text {th }}$ Edn. Reprinted, Arnold-Heinemann Publishers (India) Private

\section{Limited.}

Wijma, K., 2016. Supporting poultry gut health with essential oils. Gut Health-October. pp.58-59.

Yanishlieva, N.V., Emma Marinova, E., Pokorný, J., 2006. Natural antioxidants from herbs and spices. Eur. J. Lipid Sci. Technol. 108(9), 776-793.

Yazdanparast, R., Shahriyary, L., 2008. Comparative effects of Artemisia dracunculus, Satureja hortensis and Origanum majorana on inhibition of blood platelet adhesion, aggregation and secretion. Vascular Pharmacol. 48(1), 32-37.

Yegani, M., Smith, T.K., Leeson, S., Boermans, H.J., 2005. Mycotoxins - Part II: Is there a practical solution to mycotoxin control? World Poultry J. 21(11), 34-36.

Yiannikouris, A., Jouany, J.P., 2002. Mycotoxins in feeds and their fate in animals: A review. Anim. Res. 51, 81-99.

Zanic-Grubisic, T., Zrinski, R., Cepelak, I., Petrik, J., Radic, B., Pepeljnjak, S., 2000. Studies of ochratoxin A-induced inhibition of phenylalanine hydroxylase and its reversal by phenylalanine, Toxicol. Appl. Pharmacol. 167, 132-139.

Zepnik, H., Volkel, W., Dekant, W., 2003. Toxicokinetics of the mycotoxin ochratoxin A in F 344 rats after oral administration. Toxicol. Appl. Pharmacol. 192, 36-44.

\section{How to cite this article:}

Abdelhamid, A. M., Abdel Hamid, A. A. M., Khalil, W. A., Gomaa, A. H., El-Sayed, H. G. M., 2016. Further study on toxicity of the permissible (very low) level of ochratoxin A with and without essential oils on rats. Int. J. Curr. Res. Biosci. Plant Biol. 3(12), 64-83. doi: http://dx.doi.org/10.20546/ijcrbp.2016.312.009 